Utah State University

DigitalCommons@USU

\title{
Matching Watershed and Otolith Chemistry to Establish Natal Origin of an Endangered Desert Lake Sucker
}

\author{
Deanna Strohm \\ Utah State University
}

Follow this and additional works at: https://digitalcommons.usu.edu/etd

Part of the Ecology and Evolutionary Biology Commons

\section{Recommended Citation}

Strohm, Deanna, "Matching Watershed and Otolith Chemistry to Establish Natal Origin of an Endangered Desert Lake Sucker" (2015). All Graduate Theses and Dissertations. 4416.

https://digitalcommons.usu.edu/etd/4416

This Thesis is brought to you for free and open access by the Graduate Studies at DigitalCommons@USU. It has been accepted for inclusion in All Graduate Theses and Dissertations by an authorized administrator of DigitalCommons@USU. For more information, please contact digitalcommons@usu.edu.

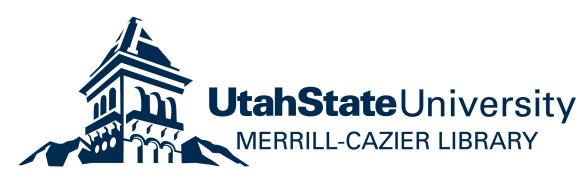


MATCHING WATERSHED AND OTOLITH CHEMISTRY TO ESTABLISH NATAL ORIGIN OF AN

\title{
ENDANGERED DESERT LAKE SUCKER
}

by

\author{
Deanna Strohm
}

A thesis submitted in partial fulfillment of the requirements for the degree

of

MASTER OF SCIENCE

in

Ecology

Approved:

Phaedra Budy

Mary Conner

Major Professor

Committee Member

Dennis Newell

Mark R. McLellan

Committee Member

Vice President for Research and

Dean of the School of Graduate Studies

UTAH STATE UNIVERSITY

Logan, Utah 
Copyright (C) Deanna Strohm 2015

All Rights Reserved 
ABSTRACT

Matching Watershed and Otolith Microchemistry to Establish Natal Origins of an Endangered Desert Lake Sucker

by

Deanna Strohm, Master of Science

Utah State University, 2015

Major Professor: Phaedra Budy

Department: Watershed Science

Like many native endemic desert freshwater fish species, the June Sucker (Chasmistes liorus) is currently listed as endangered. Implicit within the June Sucker recovery plan, is that spawning habitat restoration must result in natural recruitment. I used otolith microchemistry to establish natal origins of the potamodromous June Sucker endemic to Utah Lake, UT, USA, ultimately in order to evaluate whether tributary habitat restoration results in natural recruitment. My specific objectives included; 1 ) quantify and characterize the extent of chemical variation among the three main spawning tributaries; 2) determine the relationship between otolith microchemistry and tributary chemistry; and 3) develop and validate a classification model to identify stream origin. I quantified the molar ratios $\mathrm{Sr}: \mathrm{Ca}, \mathrm{Ba}: \mathrm{Ca}$, and $\mathrm{Mg}: \mathrm{Ca}$ for water and otolith chemistry from the three main tributaries to Utah Lake, UT during the summer of 2013. 
Water chemistry differed significantly among all three spawning tributaries (Sr:Ca Pvalue <0.05; $\mathrm{Ba}$ :Ca <0.05; Mg:Ca P-value <0.05); $\mathrm{Ba}$ :Ca and Sr:Ca were identified as the most important variables driving the classification models. I observed a strong linear relationship between water and otolith microchemistry for $\mathrm{Sr}: \mathrm{Ca}$ and $\mathrm{Ba}: \mathrm{Ca}$, but not for Mg:Ca $\left(R^{2}=0.77\right.$ P-value $<.05 ; R^{2}=0.83$ P-value $<.05 ; R^{2}=.0017$, P-value $=0.71$, respectively). Based on classification models of otolith element:Ca signatures, I was able to accurately classify individual fish to their natal tributary (classification tree $89 \%$ accuracy; random forest model $91 \%$ accuracy), and was able to determine if the fish's origin is wild vs. hatchery with $100 \%$ accuracy. The use of classification trees and random forest for classification analyses may provide a more powerful method for classification in studies using otolith microchemistry. Overall, this study will aid in evaluating the effectiveness of restoration, track progress toward recovery, help prioritize future restoration plans for the June Sucker in Utah Lake, and can be applied to other imperiled system with species of conservation concern. 


\section{PUBLIC ABSTRACT}

Matching Watershed and Otolith Microchemistry to Establish Natal Origins of an Endangered Desert Lake Sucker

by

Deanna Strohm, Master of Science

Utah State University, 2015

Major Professor: Phaedra Budy

Department: Watershed Science

Like many native endemic desert freshwater fish species, the June Sucker (Chasmistes liorus) is currently listed as endangered. Managers have increasingly turned to habitat restoration as a key component to recovery plans. For endangered species, one of the primary outcomes of habitat restoration is that it should result in successful reproduction and recruitment of individuals into the adult population. Confirmation of natural recruitment as a function of habitat restoration can only be achieved by establishing natal origins.

Recent research has proven the validity of otolith microchemistry, a technique that analyzes small quantities of elements, to trace potamodromous fish to their natal tributaries. Previous studies have documented that localized habitats in terms of microchemistry are reflected in otolith composition, thereby potentially making this a 
valuable way of determining fish origins. The primary goal of this study is to use otolith microchemistry to establish natal origins of June Sucker, ultimately in order to evaluate whether tributary habitat restoration results in natural recruitment. To accomplish this I first determined if the water chemistry among the three main spawning tributaries differed from one another. Second, I determined if the otolith chemistry reflected the otolith chemistry. Lastly, I developed a statistical model capable of classifying fish to their respective tributary based the element:calcium ratios in the otolith microchemistry.

Water chemistry differed significantly among all three spawning tributaries, and I observed a strong and significant relationship between otolith chemistry and water chemistry. The classification models based on otolith element:Ca signatures were capable of accurately classifying individual fish to their natal tributary (classification tree $89 \%$ accuracy; random forest model $91 \%$ accuracy), increasing the ability to determine if the fish's origin is wild vs. hatchery. The data obtained from this study will advance the current understanding of the June sucker recruitment dynamics and result in a fundamental improvement in our ability to determine where natural recruitment into the adult spawning population is occurring. In addition, this knowledge may help evaluate factors limiting recruitment in Utah Lake tributaries, identify future restoration localities, and assist effectiveness monitoring of spawning habitat restoration efforts. 


\section{ACKNOWLEDGMENTS}

I would like to thank the June Sucker Recovery Implementation Program, U.S. Geological Survey, the Department of Watershed Sciences, and the Ecology Center for providing funding and support throughout the duration of this project. I would especially like to thank my major advisor, Dr. Phaedra Budy, who has been an incredible mentor and role model, and has given me immense guidance and support. I would like to thank my committee members, Dr. Dennis Newell and Dr. Mary Conner, for all their guidance throughout this project. I would also like to thank Dr. Todd Crowl for initially taking me on as a graduate student, for his creative idea for this project, and for giving me the opportunity to accomplish my goals. A great deal of thanks is owed to the former Crowl Aquatic Ecology Lab, and the Fish Ecology Lab for their help and support. I would like to thank David Pluth and David Tinsley for all their hard work and support throughout the field season, and Kevin Landom for believing in me and seeing my potential as a graduate student. I would like to thank my first female role model, my mother, Deborah DeHaan D.D.S., M.S. for always loving and supporting me throughout my life, and encouraging me to follow my dreams. Finally, thanks to all of my family and friends who have been there for me throughout this entire process; for without all of you, none of this would have been possible.

Deanna Strohm 
CONTENTS

Page

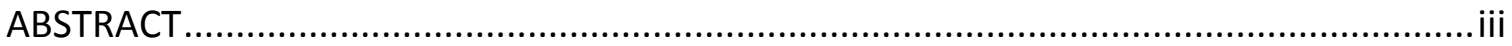

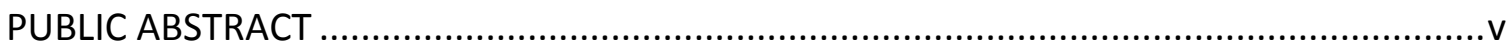

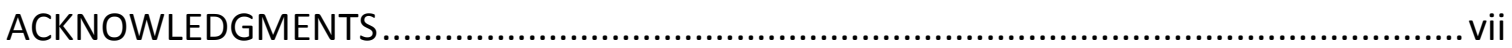

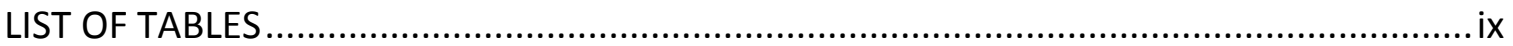

LIST OF FIGURES

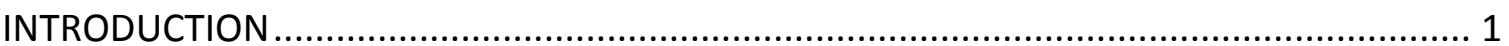

METHODS

Study Site and Organism .................................................................................. 6

Quantifying the Extent of Chemical Variation Among Spawning Tributaries ........ 9

Experimental Identification of the Unique Chemical Signature of the Tributaries

on Otolith Microchemistry .......................................................................... 10

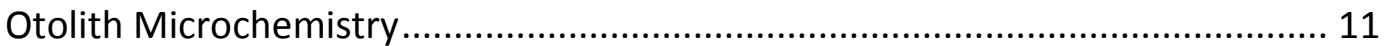

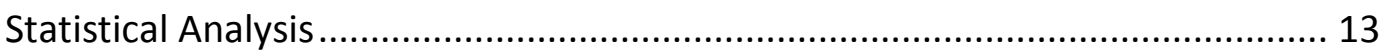

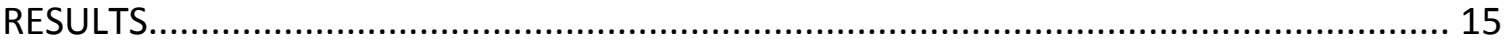

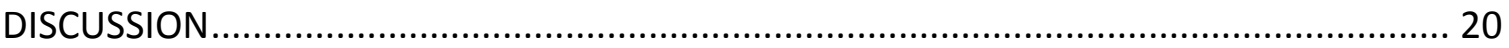

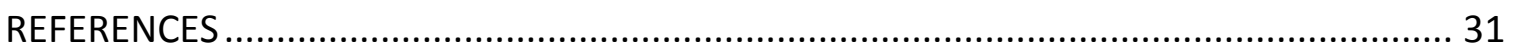

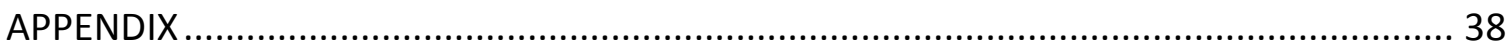




\section{LIST OF TABLES}

Table

1 Non-parametric Kruskal-Wallis Test for Water Chemistry

2 Out of bag confusion matrix for the random forest classification model based on sagittal otolith chemistry.....

3 The ten-fold cross validated confusion matrix for the classification tree model

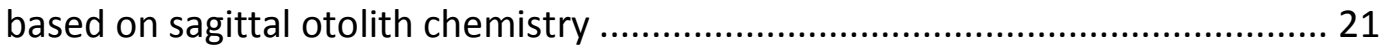

A.1 Average total length $( \pm S D ; m m)$ of June Sucker's at the beginning and end of the

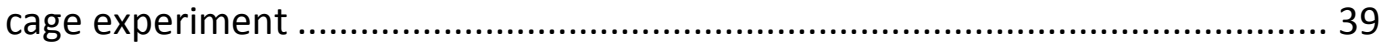

A.2 Average background corrected and normalized June Sucker otolith data ......... 40

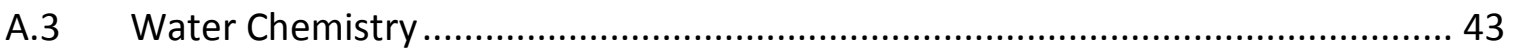




\section{LIST OF FIGURES}

Figure

1 The location of Utah Lake and its major tributaries, shown within the state of Utah.

2 Boxplots of log transformed element:Ca ratio of water chemistry.

3 Classification tree for the tributary and hatchery water chemistry data

$4 \quad$ Linear regression otolith chemistry against water chemistry for the three tributaries and hatchery

5 Variable importance plot for predictor variables from the random forest model using water chemistry data

6 Classification tree of fish to respective tributary based on concentrations of log element:Ca ratios in otoliths

$7 \quad$ Non-metric multidimensional (NMDS) scaling ordination of otolith

Microchemistry

A.1 Exponential model for the June Sucker Ba partition coefficeint as a function of stream temperature $\left({ }^{\circ} \mathrm{C}\right)$......

A.2 Boxplots of log transformed element:Ca ratio of water chemistry from each tributary for each element.

A.3 Geologic map of Utah Lake Utah, and its tributaries 


\section{INTRODUCTION}

Anthropogenic alterations to lotic freshwaters including stream fragmentation, sediment loading, introduced non-native species, and revised flow regimes, are linked to alarming rates of decline in freshwater fauna throughout the nation (Ricciardi and Rasmussen 1999; Jelks et al. 2008). Freshwater fish, in particular, have experienced one of the fastest rates of decline of all species globally (Ricciardi and Rasmussen 1999). Since 1900, there have been 57 extinctions observed in freshwater fish species in North America alone (Miller et al. 1989, Jelks et al. 2008). Alterations in flow regimes for agricultural and urban uses are a primary cause of habitat degradation, by reducing seasonal base flows and modifying the duration, frequency, and magnitude of high flow events (Budy et al. 2015). Changes in flow regimes influence the physical, biological, and abiotic conditions of the stream by altering riparian vegetation, channel morphology, habitat diversity, and temperature and dissolved oxygen patterns (Stromberg et al. 2005; Budy et al. 2015). Current rates of extinction for freshwater fishes are roughly 960 times greater than historic background rates from fossil record, likely due to these anthropogenic alterations (May et. al 1995; Pimm et al. 1995; Burkhead 2012).

Freshwater species in the arid, western United States have proven exceptionally vulnerable to human disturbance. This vulnerability is due, in part to a high amount of endemism and competition with humans for water resources; thus, a significant proportion of species have already gone extinct and many desert fish species are currently listed as threatened or endangered (Minckley and Douglas 1991; Burr and Mayden 1992; Roni et al. 
2002). In addition, many non-game species are perceived to lack charisma and have no economic value, and therefore, have been understudied (McKinney 1999, Budy et al. 2015). As a result, large knowledge gaps remain about the natural history and ecology of early life stages of many endemic western fishes further hindering our conservation success (Gadomski et al. 2001; Cooperman and Markle 2003). Furthermore, specific evolutionary life histories driving resource and habitat use (e.g., potamodromy) can further complicate their management and conservation (Olden et al. 2008; Laub et al. 2015).

Among the arid freshwater systems in the western United States, desert lakes are highly dynamic ecosystems, as they experience a wide range of natural disturbances such as drought, erosion, and extreme temperature and water level fluctuations (Scheffer 2001; Buelow 2006). The fishes that persist in these volatile conditions often express highly specialized suite of life history traits including; large body size, long life span, delayed maturity, and specialized feeding behaviors (Gaston 1994; Olden et al. 2008). Species with these biological life history traits are often more vulnerable to long-term changes in the environment and have a higher risk of extinction (Olden et al. 2008). In addition, some desert lake fish species are potamodromous, demonstrating migrations from a lake habitat into tributary habitats to spawn. Fishes expressing potamodromy are vulnerable to stream habitat degradation, because they require the use of tributaries for spawning and early life stages (Santos et al. 2011). These tributaries are often exposed to significant water development and regulation, which often results in extreme degradation to spawning and rearing habitat. Reduced flows during critical spawning 
and rearing months, limit suitable spawning habitat access, reduce habitat diversity, and decrease connectivity to rearing habitat for the June Sucker. As stream habitat restoration has necessarily become a key component to many recovery efforts for endangered fish species, there is a need for tools to aid managers in more rapidly evaluating critical areas for conservation.

The primary goal of localized stream habitat restoration is to reverse physical damage and increase habitat heterogeneity, and in-turn, induce a favorable ecological response (Palmer et al. 1997; Bond and Lake 2003). Habitat restoration approaches such as, channel and streambed reconfiguration, placement of in-stream structures, and riparian vegetation establishment, often focus on critical spawning and nursery habitat for early life stages (Kauffman et al. 1997). During the early life stages of development, fishes naturally experience the highest rates of mortality; consequently, the early life stages can be one of the most critical time periods determining population success (Schiemer et al. 2002). However, identifying optimal locations for restoration of critical spawning and nursery habitat, and assessing the effectiveness of habitat manipulations in restoring ecosystem structure and function is rarely properly evaluated often due to time, effort, and financial constraints (Bond and Lake 2003; Budy and Schaller 2007).

One of the most critical components to recovery of an endangered fish is that reproduction results in successful recruitment of young into the adult spawning population (NCR 1995; Budy and Schaller 2007). As such, improving natural recruitment is often the 
primary justification for habitat restoration efforts (Budy and Schaller 2007); however, it is often challenging to determine if habitat restoration actually results in natural recruitment. One way to determine if habitat restoration enhances natural recruitment is to determine the natal origin of newly recruited individuals. In other words, are fish successfully spawning in areas of better habitat quality and/or areas of restoration focus? Knowing the localities where fish reproduction has been successful can allow managers to evaluate factors that both limit and promote recruitment and track progress toward recovery. Otolith microchemistry has recently become a useful tool to determine the natal origin and track movement of fish in marine environments, and is increasingly being used in freshwater systems (Elsdon et al. 2008). This technique could be used to determine natal origin and thus aid in evaluating habitat restoration effectiveness by determining if areas of habitat restoration are successful in enhancing natural recruitment.

Recent research has proven the validity of otolith microchemistry, a technique reliant on measuring the elemental chemistry in otolith calcium carbonate, to trace potamodromous fish to their natal tributaries, as well as, answer a variety of pressing ecological questions (Elsdon et al. 2008). Otoliths accrete new calcium carbonate (aragonite) and protein onto the surface daily (Campana 1999, Elsdon et al. 2008), and along with daily accretions of aragonite, trace elements with a similar charge to calcium are substituted for calcium during crystallization (Bickford and Hannigan 2005). Trace elements are incorporated into the crystalline matrix in proportion to their abundance in the ambient water (Elsdon et al. 2008; Pangle et al. 2010). 
Otoliths are acellular and metabolically inert, so any element substituted for Ca onto the growing surface is permanently retained.

When a fish experiences changes in its chemical environment, those changes are recorded onto the surface of the otolith (Campana 1999), a record of the fish's environmental experiences. The core of the otolith represents the origin of its birth, and the outer-most ring of the otolith represents its most recent life experiences to the time of death. In order to track fish movement using otolith michrochemistry, there must be significant differences in water chemistry among the water bodies of interest, they must be temporally stable, and the differences in water chemistry must be reflected in the otolith chemistry. Previous studies have documented that localized habitats, are reflected in otolith composition in terms of microchemistry, thereby potentially making this a valuable way of determining fish origins (e.g., Wells et al. 2003; Bickford and Hannigan 2005; Pangle et al. 2010).

The June Sucker (Chasmistes liorus), is currently listed as endangered, and numerous management actions, including tributary habitat restoration, have been implemented in hopes to recover this highly imperiled species. Before European settlement in 1849 June Suckers were historically abundant in Utah Lake (Janetski 1990); however, in 1997 there were estimates of as few as 300 wild spawning individuals in the population (USFWS 1999; Cooke et al. 2005). When listed as endangered in 1986, little to no evidence existed to indicate successful June Sucker reproduction in the wild. The few spawning adults caught were primarily spawning in 
the Provo River (Radant 1986), with little knowledge of reproductive activity in the other five historical spawning tributaries.

Based on preliminary analysis of water chemistry, I hypothesized that otolith microchemistry could be used to determine the natal origin of the endangered June sucker, in order to address one of the current knowledge gaps of June Sucker recruitment. My specific objectives were to: 1) quantifying and characterize the extent of chemical variation among the three main spawning tributaries; 2) understand the relationship between June Sucker otolith microchemistry and tributary chemistry and; 3) develop and validate a model to identify stream origin using otolith microchemistry data. The data obtained from this study will advance the current understanding of June Sucker recruitment dynamics in Utah Lake and its three main tributaries, by improving our ability to determine the occurrence and location of natural recruitment into the adult spawning population. In addition, the information gained from this study has implications for other imperiled potamodramous species of conservation concern.

\section{METHODS}

\section{Study site and organism}

The endemic June Sucker (Chasmistes liorus) is potamodromous, demonstrating migrations from a lake habitat, Utah Lake, UT, into now degraded tributary habitats to spawn

(Figure 1). Over the past twenty-five years, management efforts have included captive rearing and augmentation, common carp (Cyprinus carpio) removal, revised tributary flow regimes, and 
spawning habitat restoration projects. Hobble Creek underwent a delta restoration project in 2008, designed to relocate the channel and reconnect it to Utah Lake to promote June sucker spawning, rearing, and recruitment (USDI 2008). A similar delta restoration project for Provo River is currently being planned. While significant efforts have been made to conserve the species, it is unknown if sufficient natural recruitment into the population is occurring.

Utah Lake is a remnant of Pleistocene Lake Bonneville (Buelow 2006), and as one of the largest natural freshwater lakes west of the Mississippi, it has a surface area of approximately $388 \mathrm{~km}^{2}$ (Figure 1). Utah Lake has a relatively small volume compared to its large surface area, due to a relatively shallow depth, with an average depth of 2.9 meters and a maximum depth of 4.2 meters. Utah Lake is fed by three major tributaries: Provo River, Hobble Creek, Spanish Fork; and three minor tributaries: American Fork, Battle Creek, and Spring Creek (Figure 1). June Sucker have been anecdotally documented spawning in all six of these tributaries in recent years, with a notably large proportion of fish spawning in the Provo River compared to the other tributaries. However; the historic flow regimes and morphologic features of these tributaries have been dramatically altered for urban and agricultural purposes. In addition, the native food web of Utah Lake has been dramatically altered. Historically, the Utah Lake food web consisted of 14 native fish species; however, today almost all of native species have been extirpated, one species is extinct, and the June sucker is listed as endangered. The June Sucker and the Utah Sucker (Catostomus ardens) are the only native species in the lake, and the 16 non-native introduced species in the Utah Lake are all potential competitors and predators of 
the June Sucker. In addition, common carp make up $>80 \%$ of the lakes biomass and have been in part, responsible for an ecosystem state change, from a vegetated, clear lake, to a turbid, eutrophic lake. Alterations to tributary flow regimes, nonnative introductions, in addition to spawning and nursery habitat loss, all pose a significant threat to the survival and recovery of the June Sucker.

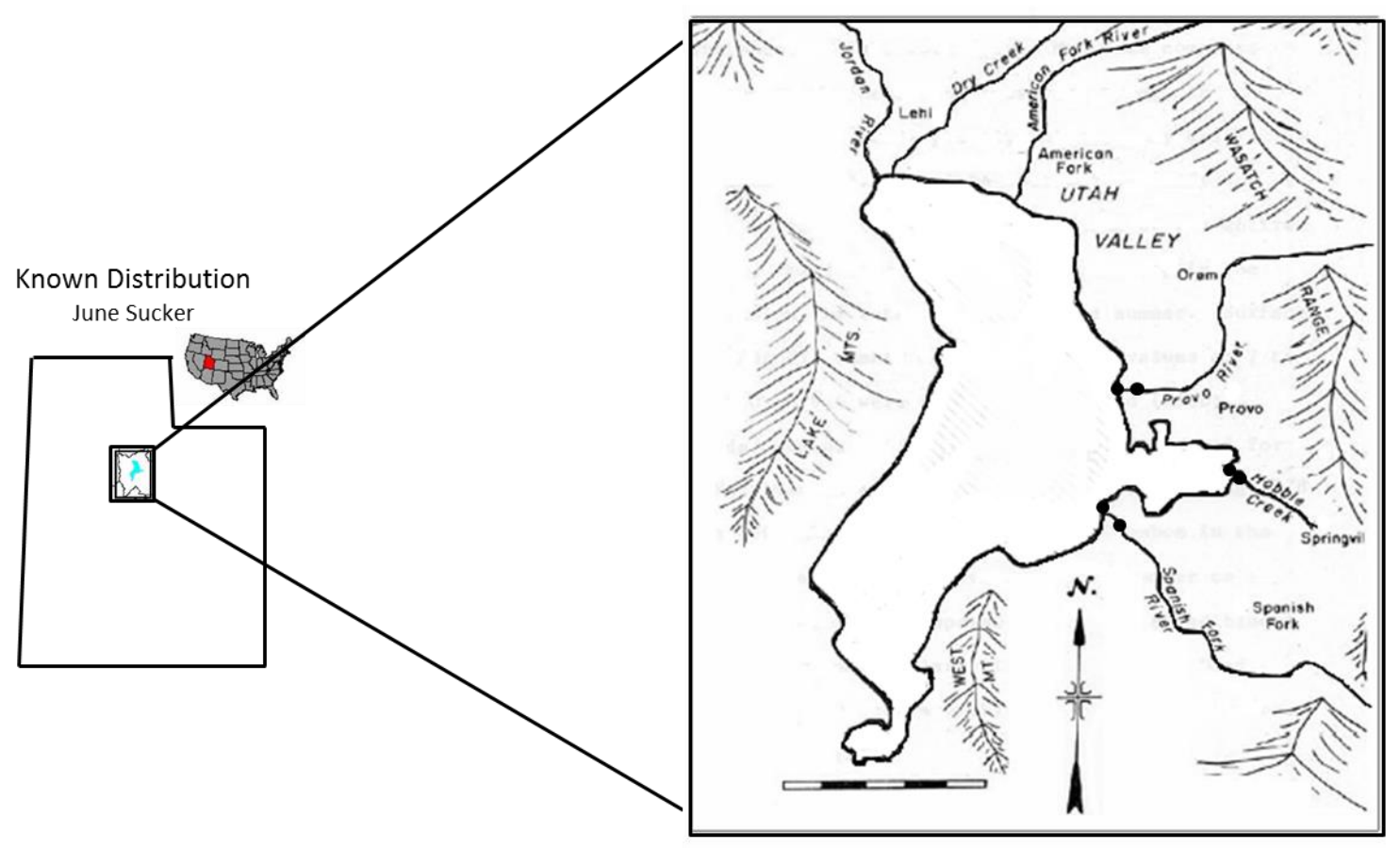

Figure 1. The location of Utah Lake and its major tributaries; Provo River, Hobble Creek, and Spanish Fork, shown within the state of Utah. The dots indicate the upstream and downstream study site locations where monthly water chemistry was collected and the fish cages incubated during the summer of 2013. Picture modified with permission from Buelow 2006 


\section{Quantifying the extent of chemical variation among spawning tributaries}

To determine the extent of chemical variation in water chemistry among tributaries, I collected water samples within each of the three major tributaries; Provo River, Hobble Creek and Spanish Fork. The water samples were taken at documented spawning sites to represent the area where egg development and initial elemental accretion will begin. I collected water samples each month throughout the summer (June - end of August 2013) to detect intra-annual variation in major and trace element chemistry that might occur. I collected two 60 milliliter water samples from an upstream and downstream site within each tributary separated by one to three kilometers in distance. The stream water was filtered through $0.45 \mu \mathrm{m}$ sterilized nylon membrane filter and placed in clean plastic Nalgene ${ }^{\circledR}$ containers. I acidified the samples on site with concentrated nitric acid to a concentration of $1 \%$ of the $60 \mathrm{ml}$ sample for preservation up to six months. The water samples were analyzed at Utah State University Water Research Laboratories using inductively coupled plasma mass spectrometry (ICP-MS). In addition, I collected water quality data at time of sampling, including: temperature, $\mathrm{pH}$, conductivity, salinity, total dissolved solids, and dissolved oxygen with an YSI Professional Plus Series multiparameter meter. 


\section{Experimental identification of the unique chemical signature of the tributaries on otolith microchemistry}

To determine if there was adequate variation in otolith microchemistry to discriminate among the different tributaries, I conducted an in situ natural cage experiment. I constructed cages out of 6 inch diameter PVC pipe; and stocked the cages at the upstream and downstream site in each tributary with month old June Suckers obtained from the Utah Division of Wildlife Resources, Fisheries Experimental Station (FES). I measured a subsample of fish for total length to the nearest $\mathrm{mm}$ before being placed in the cages. I placed three replicate cages at the upstream location and an additional three were placed at the downstream location (Figure 1). I placed the downstream cages near the mouth of the stream at the lake interface to allow for comparison between lake influences on tributary signals. The upstream cages remained at the spawning location to incorporate the natal signature during egg incubation and swim-up. I stocked the cages with ten to fifteen fish per cage for a total of six cages per stream resulting in approximately sixty to ninety fish per tributary. To develop a strong elemental otolith signature

for each tributary, the cages remained in the stream from July $17^{\text {th }}, 2013$ to August $30^{\text {th }}, 2013$. All of the cages and fish were lost at the upstream site of the Spanish Fork due to a high water event, and two cages were lost on the Provo River upstream site due to vandalism.

At the end of the experiment I collected fish from cages, euthanized them, measured total length to the nearest $1 \mathrm{~mm}$ (Table A.1), and immediately transferred the fish into clean glass shell vials and placed them on ice until they were able to be frozen. Whole fish were kept 
frozen until otoliths were extracted. I extracted the lapilli and sagittal otoliths under a dissecting microscope with cleaned tools that were non-metallic, or otherwise wrapped in Teflon. Once the otolith was out of the endolymph sac, I cleaned it of remaining tissue and rinsed with it deionized water. The cleaned otoliths were then adhered to glass slides with double-sided tape. Mounted otoliths were taken to Woods Hole Oceanographic Institution Plasma Mass Spectrometry Facility, where I analyzed them for a suite of trace elements using laser ablation inductively coupled plasma mass spectrometry (LA-ICPMS).

\section{Otolith microchemistry}

I used the Finnegan Element MAT 2 high-resolution inductively coupled plasma mass spectrometer, equipped with a new Wave 193-nm laser ablation system to analyze otolith microchemistry. Sagittal and lapilli otoliths from fish were analyzed for a suite of elements including $\mathrm{Ca}, \mathrm{Ba}, \mathrm{Mg}, \mathrm{Mn}, \mathrm{Sr}, \mathrm{Pb}$ and $\mathrm{U}$. However, initial screening of the data revealed sagittal otoliths had higher and more consistent concentrations of elements and thus were used for all further analyses. To examine the most recent period of the fish's life, representing the time in the stream, I ablated a $50 \mu \mathrm{m}$ pathway around half of the outer perimeter of the otolith with the laser. I used raw (e.g., unsectioned, unpolished) otoliths and measured otolith element concentrations along the outer edge (vs. a transect across the otolith) of the otolith, in order to capture the most recent time of the fish's life, i.e. the time spent in the tributary (Pangle et al. 2010). 
To correct for machine drift, background noise, and normalize the data; a gas blank, FEBS-1 otolith standard, and NIES-022 standard were analyzed before and after every tenth sample in the ablation sequence. I corrected the raw data output for background noise by subtracting the average blank values from the average intensity for each element concentration. I then normalized the background corrected data to the FEBS-1 calcium standard according to the following equation (1):

(1) element: $C a=\frac{I_{\text {element sample }}}{I_{\text {Ca sample }}} \times\left[\frac{C_{\text {element standard }}}{C_{\text {Ca standard }}} \times \frac{I_{\text {Ca Sample standard }}}{I_{\text {element sample Standard }}}\right]$ where $I_{\text {sample }}$ is the element intensity from the ablation (cps), $I_{\text {sample standard }}$ is the element NRC standard average from each sequence run, and C is the average NRC otolith standard concentration (ppm) from the sequence (Lee C-T A. 2006). For an element to be included in the analysis, it had to be above the limit of detection (LOD), and it had to be measured precisely (Pangle et al. 2010). To meet the LOD, the element had to be greater than three standard deviations of the average background levels for that element. Manganese, $\mathrm{Pb}$, and $\mathrm{U}$ failed to meet the limit of detection and were removed from further analysis. I calculated the relative standard deviation (RSD) for each element, as the standard deviation/mean x 100; which serves as measurement for precision (Hand et al. 2008). A low RSD value indicates low variability of the data and greater precision. The lower limit for precision was set at $10.5 \%$, if the RSD was above $10.5 \%$ it was considered to not be measured precisely and it was removed from the data set (Hand et al. 2008). I reported the mean element:Ca values in parts per million (ppm) for the 
otolith edge (Table A.1). In addition, I calculated the relative concentration at which elements were incorporated into the otolith with respect to their occurrence in the ambient water as the partition coefficient; where the partition coefficient= (element:Ca) $)_{\text {otolith }} /(\text { element:Ca })_{\text {water }}$ (Campana 1999).

\section{Statistical analysis}

I first performed descriptive statistics to asses normality and homoscedasicity for otolith and water element:Ca data. All of the data were log transformed prior to statistical analysis, which slightly improved normality and heteroscedasicity. To quantify the extent of chemical variation among spawning tributaries, and to determine if there was evidence of intra-annual variation in water chemistry, I performed Kruskal-Wallis tests on the water chemistry data. The Kruskal-Wallis was chosen over the ANOVA because the water chemistry data are not normally distributed. The Kruasal-Wallis is a non-parametric; therefore, does not assume normal distribution; it assigns a rank to each observation in the data-set, to test the nullhypothesis that the mean ranks of the groups are the same (McDonald 2014). To identify the unique chemical signature of the tributaries, I developed two classification models, a classification tree model and a random forest model, both for the water chemistry data (Cutler et al. 2007). To explore the relationship between otolith chemistry and tributary chemistry, I first ran a linear regression; with the individual fish otolith element:Ca ratios as a function of the water chemistry element:Ca ratios. For the water chemistry parameter in the linear 
regression, I chose the mean element:Ca ratio from the water chemistry data with date closest to fish removal (August $15^{\text {th }} 2013,15$ days prior to fish death). Although this approach required some level of pseudo-replication (only one water sample per site), it provided a helpful preliminary graphical representation of relationship between water and otolith chemistry. In addition, I calculated the Pearson correlation coefficients to determine if there was a linear relationship between the uptake of $\mathrm{Sr}, \mathrm{Ba}$, and $\mathrm{Mg}$ into the otolith (the partition coefficient) and water quality variables (temperature, dissolved oxygen, salinity, and $\mathrm{pH}$ ).

Next, I used two classification models, classification tree analysis and random forest model, to determine if there was adequate variation in otolith element:Ca concentrations to discriminate among tributaries in order to classify individual fish to their respective tributaries. I performed all analyses in R freeware software version 2.15.1 (R Development Core Team 2012 ) in packages MASS 7.3-18, verification 1.37, randomForest 4.6-7, rpart 4.1-8. I crossvalidated the models using a ten-fold jack-knife technique, which tests the accuracy and predictive capabilities of the classification models. Lastly, I performed non-metric multidimensional (NMDS) scaling ordination in $\mathrm{R}$, package vegan, to visually demonstrate the otolith microchemistry patterns among fish from different tributaries observed in the classification tree and random forest model. I did not log transform the data for the NMDS analysis. 


\section{RESULTS}

Water chemistry did not significantly vary temporally within any of the tributaries for from the time period of June through the end of August. Water chemistry differed significantly among all three spawning tributaries for $\log _{e}$ transformed Sr:Ca (Kruskal Wallis: $X^{2}=16.9 ; \mathrm{df}=2$; P-value <0.001); Ba:Ca Ca (Kruskal Wallis: $\mathrm{X}^{2}=8.4 ; \mathrm{df}=2 ; \mathrm{P}$-value 0.015); and Mg:Ca (Kruskal Wallis: $X^{2}=15.1 ; d f=2 ; P$-value $<0.001$; Figure 2); however, there was no significant intra-annual difference in water chemistry over the duration of the study (Table 1). Tributary water chemistry could be accurately classified based on the element:Ca ratio; classification models demonstrated $100 \%$ classification accuracy for the classification tree analysis and random forest (Figure 3). The Sr:Ca and Mg:Ca were identified as the most important variables driving the classification in both models, as indicated by the random forest variable importance plot, a variable selection method, and the classification tree (Figure 3).

Otolith microchemistry was strongly associated with the water chemistry of the respective tributaries. I observed a strong and significant linear relationship between otolith and water chemistry for Sr:Ca $\left(r^{2}=0.77 ; \mathrm{P}\right.$-value <.05) and $\mathrm{Ba}: \mathrm{Ca}\left(r^{2}=0.83, \mathrm{P}\right.$-value <.05), but not for Mg:Ca $\left(r^{2}=.0017, \mathrm{P}\right.$-value= 0.71) (Figure 4). The partition coefficients differed among elements and were calculated for the Sr:Ca ratio as $0.39(\mathrm{~N}=80 ; \mathrm{SE}=0.004) ; 0.08$ for $\mathrm{Ba}: \mathrm{Ca}$ $(\mathrm{N}=80 ; \mathrm{SE}=0.08)$; and $9.4 \times 10^{-5}$ for the $\mathrm{Mg}: \mathrm{Ca}\left(\mathrm{N}=80 ; \mathrm{SE}=4.6 \times 10^{-6}\right)$; a value of one would indicate there is no elemental discrimination (Campana 1999). The Pearson correlation 

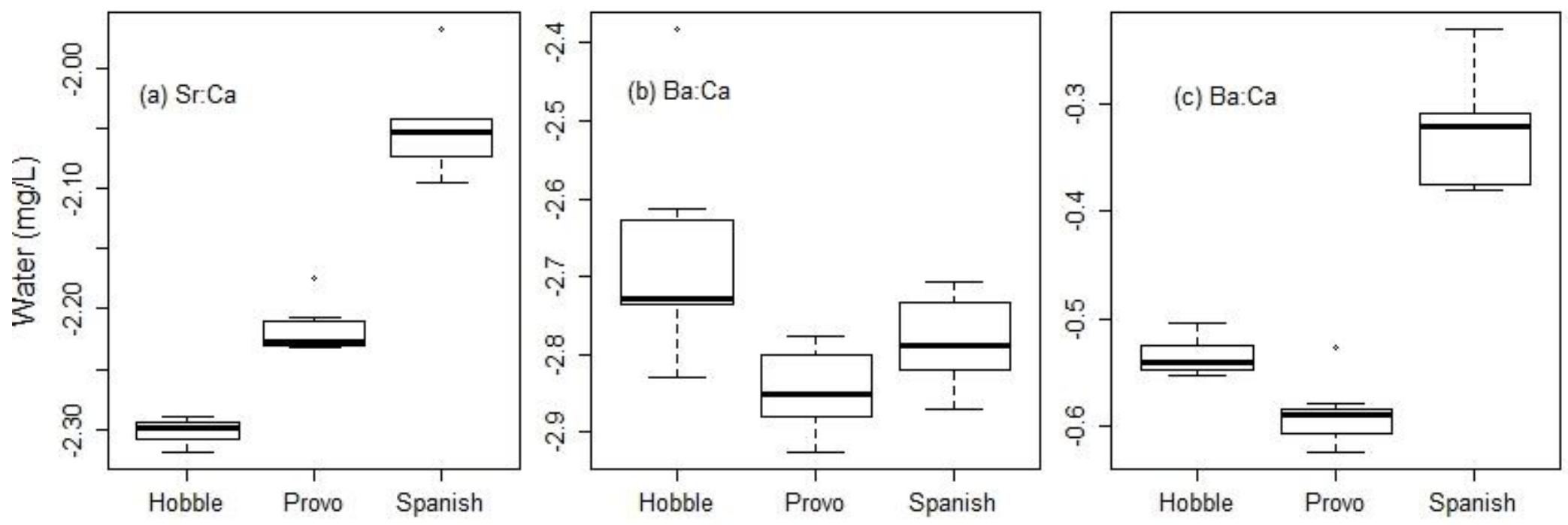

Figure 2. Boxplots of log transformed element:Ca ratio of water chemistry from each tributary for each element (Sr:Ca; $\mathrm{Ba}: \mathrm{Ca}$; and $\mathrm{Mg}: \mathrm{Ca}$ ). Horizontal lines in the boxes represent the median, the top and bottom of the box represent the first and third quantile. Water samples were collected monthly (June through end of August 2013) at the upstream and downstream study site locations within Hobble Creek, Provo River, and Spanish Fork. 
Table 1. Non-parametric Kruskal-Wallis test, showing the mean ranks of element:Ca ratio (ppm) for water chemistry are the not significantly different across sampling months (June through end of August 2013) from the three main June Sucker spawning tributaries of Utah Lake, Utah.

Kruskal Wallis

\begin{tabular}{lllll}
\hline Stream & Element & Chi squared & df & P-value \\
\hline Provo River & $\mathrm{Sr}: \mathrm{Ca}$ & 0.32 & 3 & 0.96 \\
& $\mathrm{Ba}: \mathrm{Ca}$ & 5.7 & 3 & 0.13 \\
& $\mathrm{Mg}: \mathrm{Ca}$ & 1.9 & 3 & 0.59 \\
\cline { 2 - 5 } Hobble Creek & $\mathrm{Sr}: \mathrm{Ca}$ & 2.1 & 3 & 0.54 \\
& $\mathrm{Ba}: \mathrm{Ca}$ & 5.7 & 3 & 0.13 \\
& $\mathrm{Mg}: \mathrm{Ca}$ & 5.3 & 3 & 0.15 \\
\cline { 2 - 5 } Spanish Fork & $\mathrm{Sr}: \mathrm{Ca}$ & 1.4 & 3 & 0.7 \\
& $\mathrm{Ba}: \mathrm{Ca}$ & 4.7 & 3 & 0.19 \\
& $\mathrm{Mg}: \mathrm{Ca}$ & 1.4 & 3 & 0.7 \\
\hline
\end{tabular}

coefficients indicated there was a linear relationship between the Ba partition and temperature (Pearson's correlation coefficient $=0.70$ ). However, there was severe heteroscedasticity in the standardized residuals and the data suggested an exponential model, which fit better than the linear model. The exponential model with temperature, explained a high amount of variation in Ba partition coefficient $\left(R^{2}=0.75\right.$; Figure A.1). However the model assumption of homoscedasticity was violated due to the high variation in $\mathrm{Ba}$ at low temperatures. The exponential model indicates that the Ba partition coefficient exponentially decreases as temperature increases as temperature increases; the barium decreases exponentially. There were no strong linear relationships for the Sr partition coefficient and any of the abiotic variables.

In general, the classification models performed similarly, both exhibiting relatively high overall model classification accuracy, and both exhibiting some classification error associated with two of the streams. The random forest model 
demonstrated an overall classification accuracy of $91.4 \%$, correctly classifying $83.3 \%$ of the FES hatchery fish, $100 \%$ of the Hobble Creek fish, $88.5 \%$ of the Provo River fish, and $70 \%$ of the Spanish Fork fish. This model exhibited the most error associated with the Provo River and Spanish Fork River; three fish from Spanish Fork were misclassified as Provo River fish, and three Provo River fish were misclassified as Spanish Fork fish (Table 2). The classification tree showed similar results, with an overall classification rate of

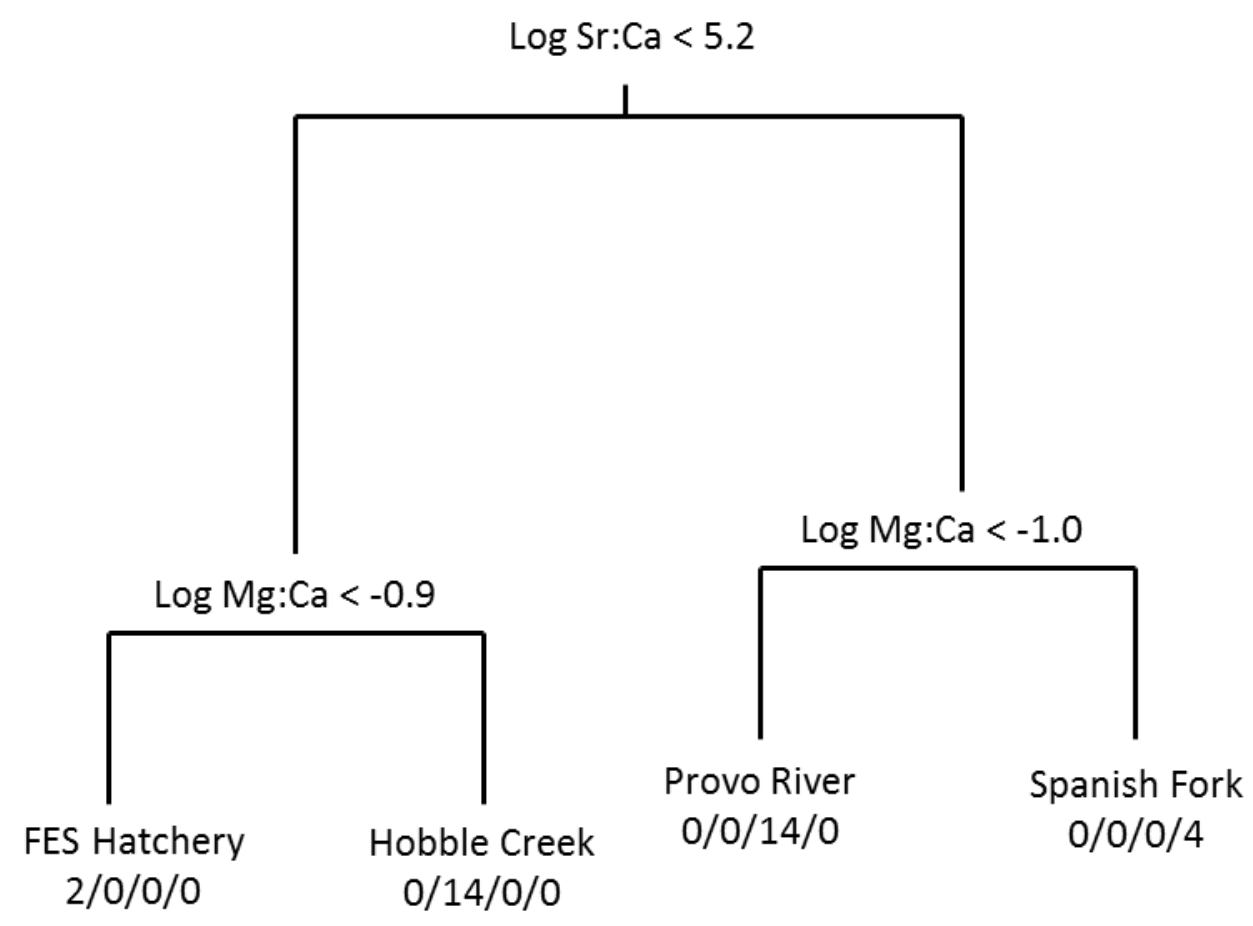

Figure 3. Classification tree for the tributary and FES hatchery water chemistry data. The data were the average element:Ca ratios ( $\mathrm{Sr}: \mathrm{Ca}, \mathrm{Ba}: \mathrm{Ca}$,and $\mathrm{Mg}: \mathrm{Ca}$ ) collected from June through August 2013, for the upstream and downstream sampling locations within each tributary. Each split in the tree is a condition for the classification. The slashes at the nodes represent each tributaruy(FES Hatchery/Hobble Creek/Provo River/Spanish Fork), and the numbers represent how many individual samples are classified to that tributary. The classification tree model is capable of predicting streams based on log element:Ca ratio with $100 \%$ accuracy. 

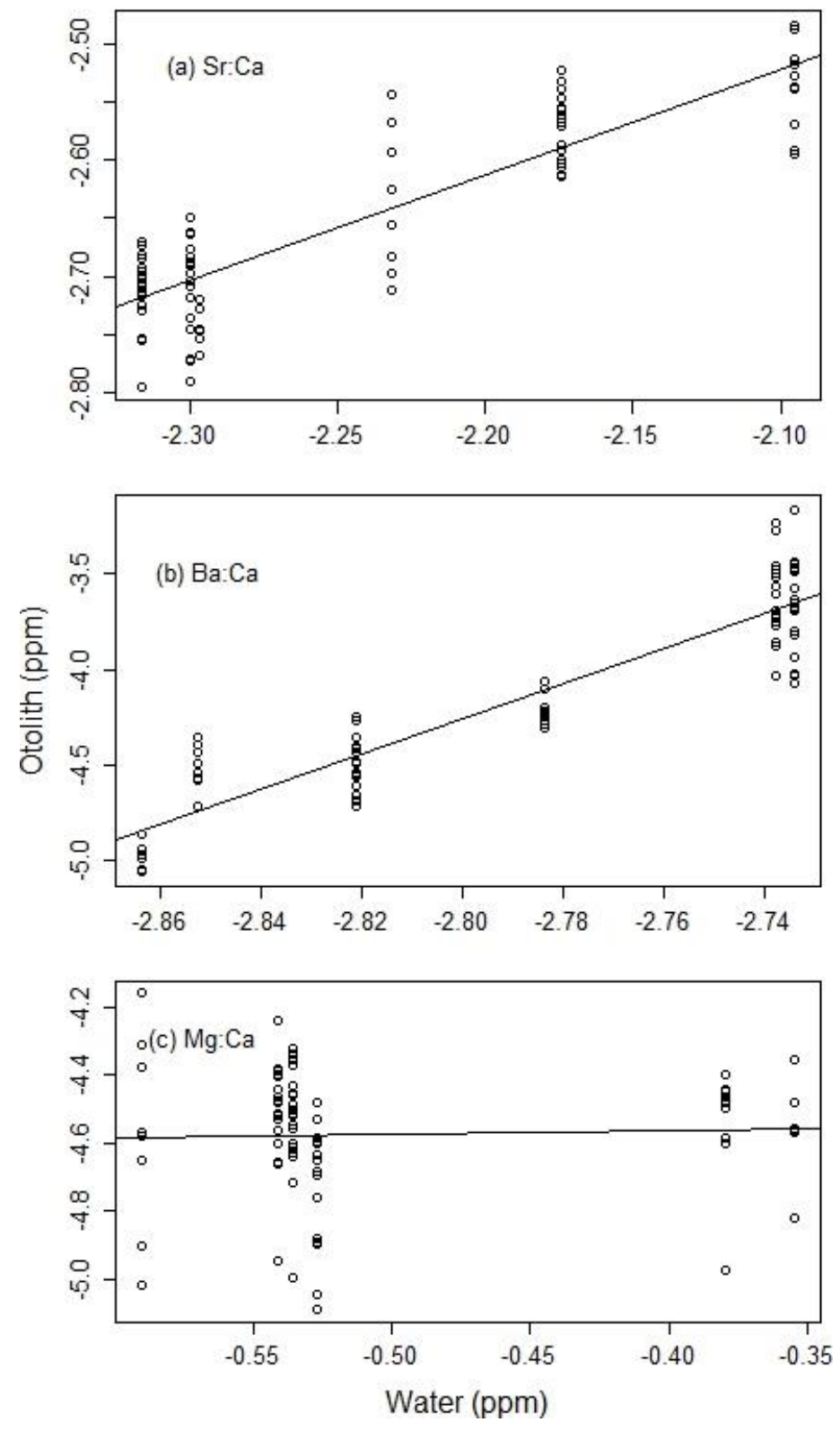

Figure 4. (a) Linear regression of Sr:Ca June Sucker sagittal otolith chemistry against $\mathrm{Sr}$ :Ca water chemistry for the three tributaries and FES hatchery. $\left(P<0.001, R^{2}=0.77\right.$, $\mathrm{n}=78$ ). (b) Linear regression of $\mathrm{Ba}: \mathrm{Ca}$ June Sucker sagittal otolith chemistry against $\mathrm{Ba}: \mathrm{Ca}$ water chemistry for the three tributaries and hatchery. $\left(P<0.001, R^{2}=0.84, n=78\right)$. (c) Linear regression of $\mathrm{Mg}: \mathrm{Ca}$ June Sucker sagittal otolith chemistry against $\mathrm{Mg}: \mathrm{Ca}$ water chemistry for the three tributaries and hatchery $\left(P<0.001, R^{2}=0.0017, n=78\right)$. 
$88.9 \%$, correctly classifying $100 \%$ of the FES hatchery fish, $94.8 \%$ of the Hobble Creek fish, $84.6 \%$ of the Provo River fish, and $70 \%$ of the Spanish Fork fish. Similar to the random forest model, three fish from the Provo River were misclassified as Spanish fork fish, and three fish from the Spanish Fork were misclassified as Provo River fish as indicated by Table 3.

The most important variables driving the classification models were Ba:Ca and Sr:Ca ratios in the otoliths. The random forest variable importance plot, and the fitted classification tree, both identified Ba:Ca and Sr:Ca as the most important elements driving the model respectively (Figure 5 and 6). Hobble Creek has the highest Ba:Ca ratio among all the tributaries and was the first condition identified in the classification tree, followed by further splits in the Sr:Ca ratios. The 'important variable selection' procedure for the random forest indicated otolith $\mathrm{Mg}$ :Ca ratio was the least important variable in the classification model for the otolith chemistry (Figure 5); this pattern was also observed in the classification tree model (Figure 6). The NMDS ordination clearly demonstrates the separation and overlaps in otolith chemistry among tributaries (Figure 7); FES hatchery and Hobble Creek demonstrate complete separation, and conversely otolith chemistries from Spanish Fork and Provo River demonstrated the partial overlap.

\section{DISCUSSION}

In order to evaluate whether or not habitat restoration results in or contributes to natural recruitment, it is imperative to establish the natal origin (e.g., location; 
Table 2. Out of bag confusion matrix for the random forest classification model based on 2013 June Sucker sagittal otolith chemistry from the FES hatchery and three tributaries; Hobble Creek, Provo River, and Spanish Fork, with the upstream and downstream locations pooled for each stream. The columns repersent the stream the fish were classified to. The rows represent the streams the fish came from. The last column is the percent of fish correctly classified to their respective stream (PCC).

\begin{tabular}{llllll}
\hline Stream & FES & $\begin{array}{l}\text { Hobble } \\
\text { Creek }\end{array}$ & $\begin{array}{l}\text { Provo } \\
\text { River }\end{array}$ & $\begin{array}{l}\text { Spanish } \\
\text { Fork }\end{array}$ & \multirow{2}{*}{ PCC } \\
\hline FES Hatchery & 5 & 0 & 1 & 0 & 83.3 \\
Hobble Creek & 0 & 39 & 0 & 0 & 100 \\
Provo River & 0 & 0 & 23 & 3 & 88.5 \\
Spanish Fork & 0 & 0 & 3 & 7 & 70 \\
\hline
\end{tabular}

Table 3. The ten-fold cross validated confusion matrix for the classification tree model based on 2013 June Sucker sagittal otolith chemistry from the FES hatchery and three tributaries; Hobble Creek, Provo River, and Spanish Fork, with the upstream and downstream locations pooled for each stream. The columns repersent the streamto which the fish were classified. The rows represent the streams the fish came from. The last column is the percent of fish correctly classified to their respective stream (PCC).

\begin{tabular}{llllll}
\hline Stream & $\begin{array}{l}\text { FES } \\
\text { Hatchery }\end{array}$ & $\begin{array}{l}\text { Hobble } \\
\text { Creek }\end{array}$ & $\begin{array}{l}\text { Provo } \\
\text { River }\end{array}$ & Spanish Fork & PCC \\
\hline FES Hatchery & 6 & 0 & 0 & 0 & 100 \\
Hobble Creek & 0 & 37 & 0 & 2 & 94.8 \\
Provo River & 1 & 0 & 22 & 3 & 84.6 \\
Spanish Fork & 0 & 0 & 3 & 7 & 70 \\
\hline
\end{tabular}




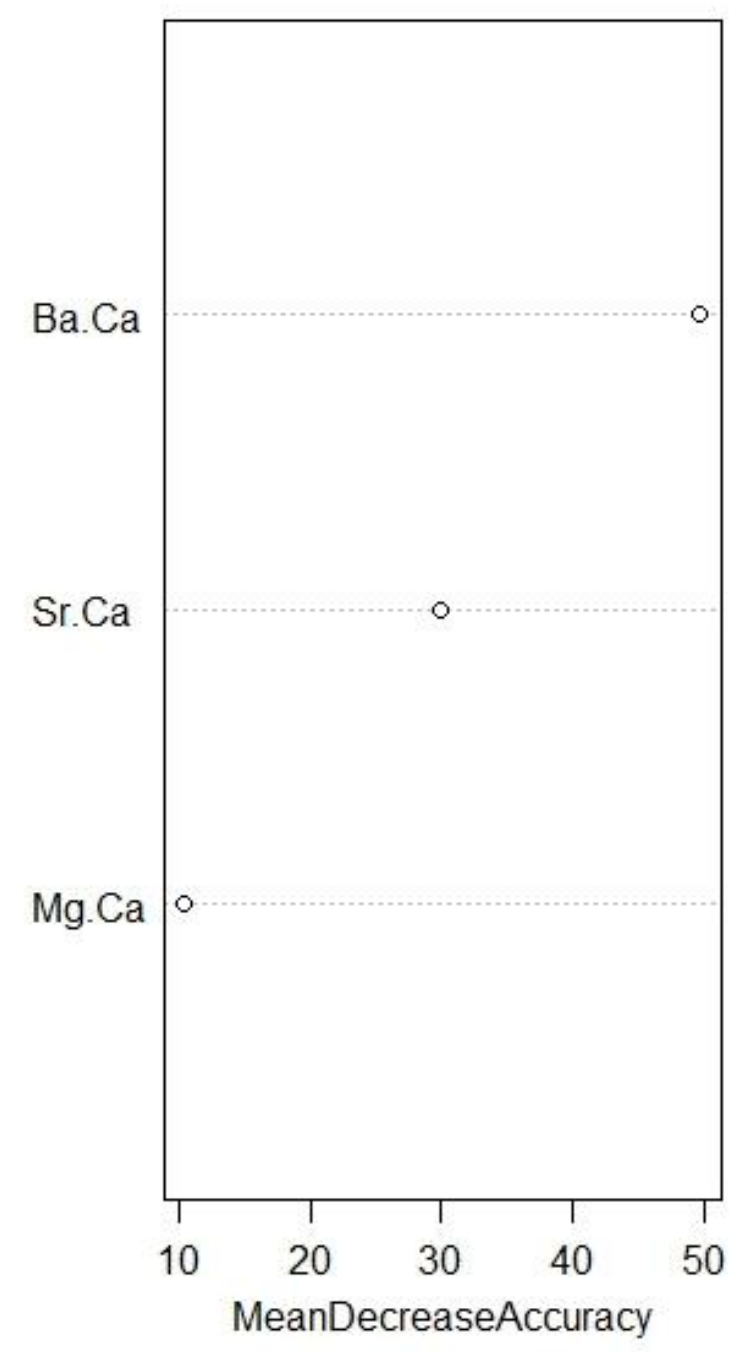

Figure 5. Variable importance plot for predictor variables from the random forest model using 2013 June Sucker otolith chemistry data. The mean decrease in accuracy indicate the importance of each predictor variable, variables with high values for mean decrease in accuracy are more important to the classification model. 


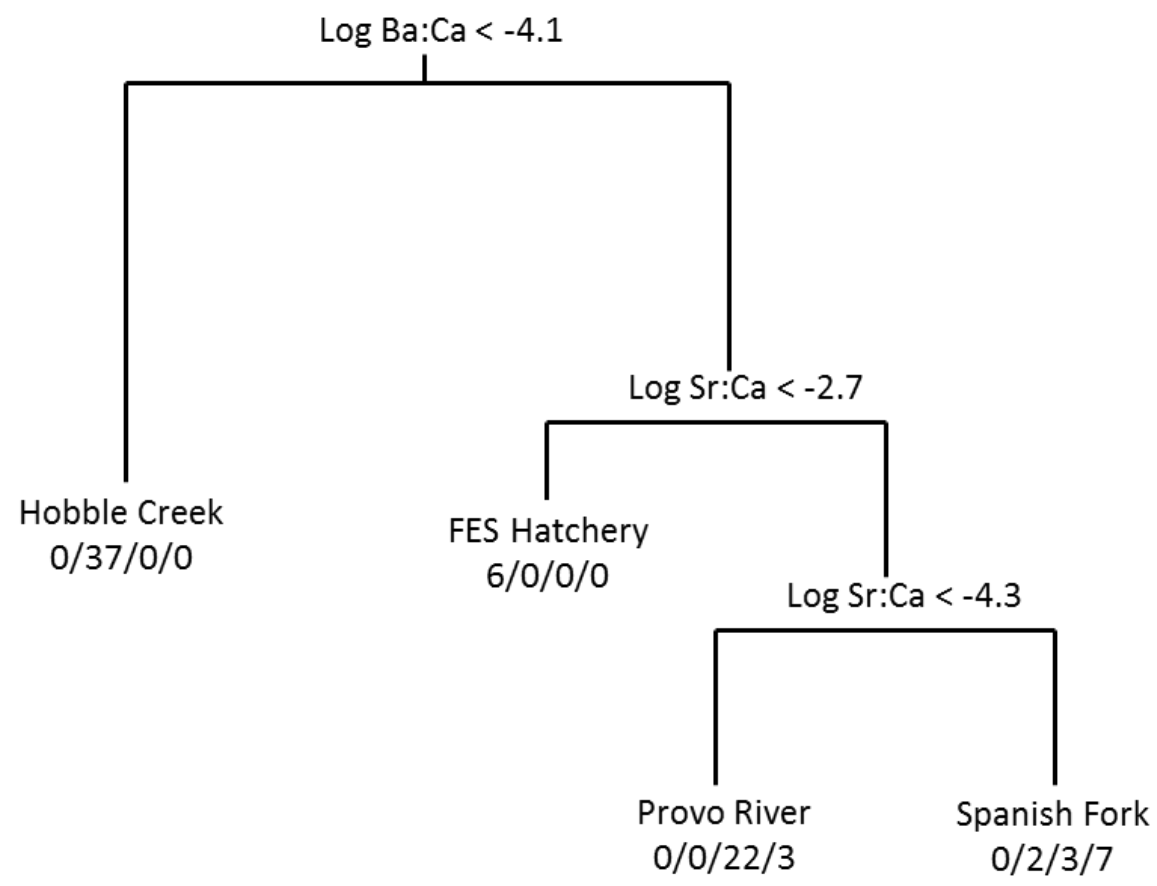

Figure 6. Classification tree of fish to respective tributary based on concentrations of log element:Ca ratios in June Sucker sagittal otoliths. The data are the average otolith element:Ca ratios ( $\mathrm{Sr}: \mathrm{Ca}, \mathrm{Ba}: \mathrm{Ca}$,and $\mathrm{Mg}: \mathrm{Ca}$ ) from LA-ICPMS of the outer edge of the otolith. Data were normalized, and measurements that did not meet the limit of detection or were not measured preciesely were removed. Each split in the tree is a condition for the classification. The slashes at the nodes represent each tributaruy(FES Hatchery/Hobble Creek/Provo River/Spanish Fork), and the numbers represent how many individual fish were classified to the tributaryat that node. The classification tree has an overall classification rate of $88.9 \%$, correctly classifying $100 \%$ of the FES hatchery fish, $94.8 \%$ of the Hobble Creek fish, $84.6 \%$ of the Provo River fish, and $70 \%$ of the Spanish Fork fish. 


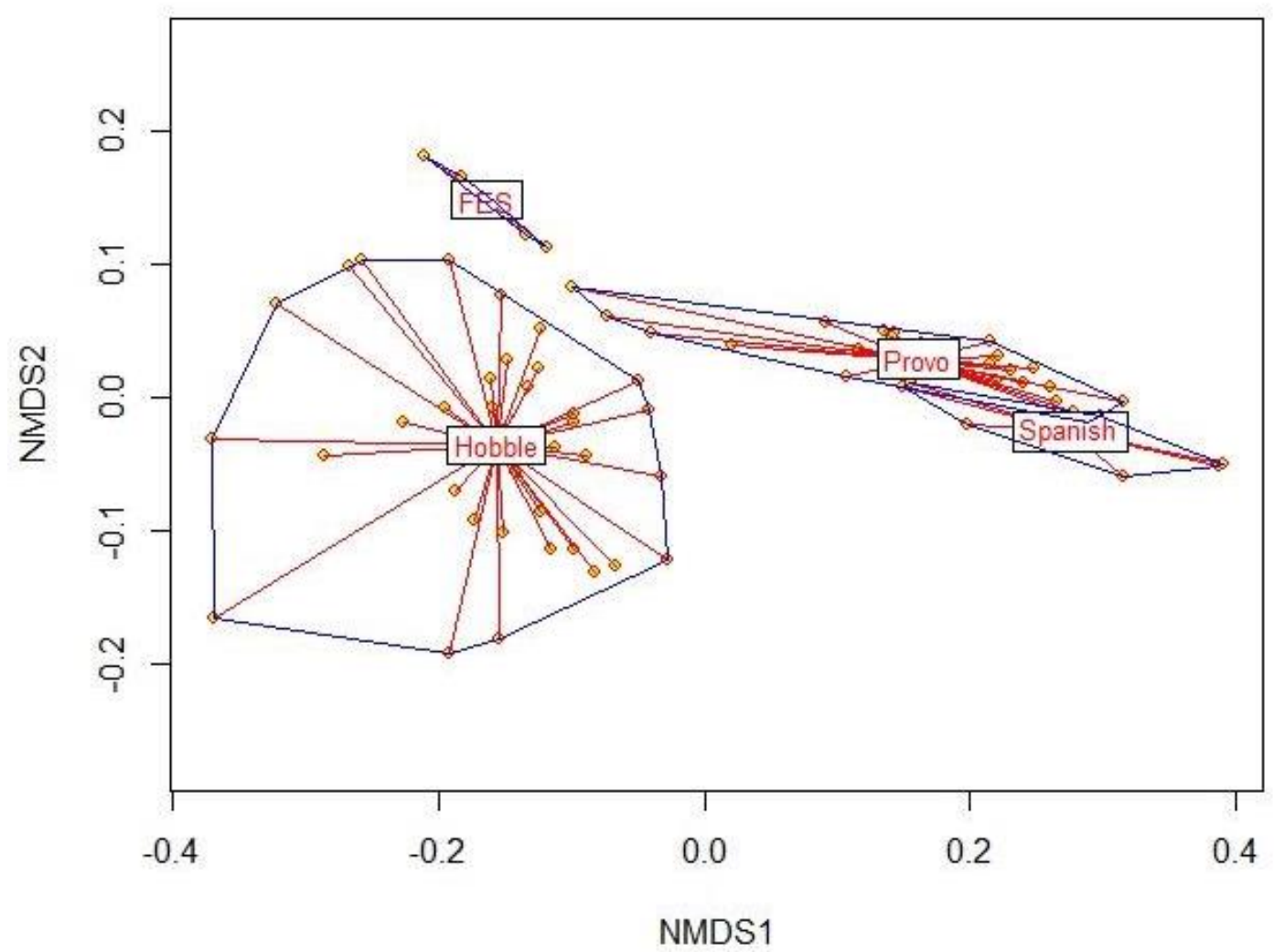

Figure 7. Non-metric multidimensional (NMDS) scaling ordination of June Sucker sagittal otolith microchemistry using predictor variables: $\mathrm{Sr}: \mathrm{Ca}, \mathrm{Ba}: \mathrm{Ca}$, and $\mathrm{Mg}: \mathrm{Ca}$. The dots indicate individual June Sucker otolith samples element:Ca ratios plotted in ordination space, fish from streams with similar otolith chemistry are plotted closer together.

hatchery vs. wild) of new individuals recruited into the adult population. My analysis of water chemistry and otolith chemistry revealed that otolith chemistry can be used to establish natal origin of the June Sucker, as well as to provide managers with a tool to determine if natural recruitment is occurring in the Utah Lake basin. The primary goal of this study was to determine if otolith microchemistry could be used as a tool to establish natal origin, to evaluate whether natural recruitment results after habitat restoration. When using otolith microchemistry as a technique to determine the natal origin, the chemistry of the tributaries must be statistically significantly different from 
one another, it must be temporally stable, and the differences in water chemistry must be reflected in the otolith chemistry.

There was significant variation in water chemistry among the three major tributaries to Utah Lake, yet stream chemistry did not vary significantly for individual streams throughout the duration of the study. The variation observed among the tributary water chemistry was likely due to the heterogeneity in the underlying geology of the watersheds. In addition anthropogenic impacts of different land uses (e.g., urban and agricultural) could influence the concentration of trace metals within the tributaries. Streams can demonstrate specific chemical signatures due to different geological characteristics, weathering processes, and groundwater recharge among respective drainages (Pangle et al. 2010). Streams within close geographic proximity can exhibit distinguishable variations in water chemistry over small spatial scales (Veinott and Porter 2004). These chemical differences in the water chemistry are directly related to the chemistry found in the otoliths. Accordingly, we observed a strong linear relationship between the element:Ca ratio in the water chemistry and the element:Ca ratio in the otolith chemistry for $\mathrm{Sr}$ and $\mathrm{Ba}$, but not for $\mathrm{Mg}$.

To date, Sr and Ba have been recognized as detectable and discriminatory trace elements for use in otolith microchemistry (Ludsin et al. 2006). Otoliths incorporate Sr and $\mathrm{Ba}$ into the aragonite in proportion to the $\mathrm{Sr}$ and $\mathrm{Ba}$ concentrations occur in the ambient water chemistry (Gibson-Reinemer 2009). Magnesium is also frequently used in otolith microchemistry; however, in this study $\mathrm{Mg}$ in the otolith did not demonstrate a linear relationship with the water chemistry. Similarly, in a recent study examining the 
incorporation of Mg into fish otoliths, Woodcock et al. (2012) also found that Mg concentrations did not change in response to $\mathrm{Mg}$ concentrations in the water, suggesting Mg may not be a reliable environmental indicator. In addition, $\mathrm{Mg}$ is a major element; therefore, the water chemistry has $\mathrm{Mg}$ concentrations several orders of magnitude higher than trace elements $\mathrm{Ba}$ and $\mathrm{Sr}$. There may be a limitation to the amount of $\mathrm{Mg}$ that can be substituted into the $\mathrm{CaCO}_{3}$ matrix of the otolith, and this limit could be related to chemical saturation of $\mathrm{Mg}$ in the otolith mineral, or a physiological regulation of how much $\mathrm{Mg}$ is incorporated into the otolith. In either case, I hypothesize the dissolved $\mathrm{Mg}$ in the water exceeds this limit such that the otolith is not sensitive to fluctuations in water chemistry; therefore no linear relationship between water and otolith chemistry is observed. If the $\mathrm{Mg}$ concentrations drop significantly below this 'limit' then it is possible it may be reflected in the otolith.

My classification models were successful in predicating fish origin based on otolith chemistry. Overall the otolith element:Ca classification models performed relatively well, with the highest classification model accuracy of $91.4 \%$ from the out-ofbag random forest, and the lowest classification accuracy of $88.9 \%$ from the ten-fold cross-validated classification tree. For comparison, classification accuracies in other somewhat similar studies have ranged from $100 \%$ to $67 \%$ for juvenile Yellow Perch (Perca flavescens) in Lake Erie tributaries (Pangle et al. 2010); and 97\% to 89\% reclassification accuracy for age-0 Alewives (Alosa pseudoharengus) and age-0 Blueback Herring (A. aestivalis) in the Delaware and Rappahannock rivers (Turner and Limburg 2014). While most otolith chemistry studies use linear or quadratic discriminant 
analyses for classification, I chose to use the classification trees and random forest to model otolith chemistry, because the techniques do not require that assumptions of normality or homoscedascisity be met and have higher classification accuracy compared to other classification models (Cutler et al. 2007, Carlisle et al. 2009). In addition, are easy to interpret (Cutler et al. 2007). The random forest models build upon the classification trees to improve classification accuracy; they have the capability of modeling complex interactions, produce variable importance plots, and are stable to small perturbations of the data (Cutler et al. 2007). In my analysis both the classification tree and random forest indicated similar results. In addition, the NMDS ordination visually supported the findings of both classification models, demonstrating the complete separation of the hatchery fish (FES) and Hobble Creek, and partial overlap between Provo River and Spanish Fork. The overlap in Sr:Ca otolith chemistry between Provo River and Spanish Fork fish may be due to the small sample size $(n=10)$ of fish from Spanish Fork, the lake influence at the downstream cage site, similar underlying geology, or some combination of these factors.

The ambient water Ca concentrations may also contribute to the observed overlap in otolith chemistry for Spanish Fork and Provo River fish. Calcium concentrations in the water have a large effect on elemental uptake (Campana 1999). In freshwater fish, the uptake of metals from the gills generally decreases as the ambient concentration of Ca in water increases (Mayer et al. 1994, Campana 1999). When ambient Ca concentration is low, a greater proportion of Ca and trace metals will be absorbed through the gills (Mayer et al. 1994, Campana 1999). This relationship may 
also explain the high Ba:Ca concentrations observed in the Hobble Creek fish (Figure A.2). Hobble Creek has significantly lower ambient Ca concentration than the other tributaries (Table A.3); it is the smallest of the three watersheds, and primarily drains sedimentary rock and Lake Bonneville clay deposits. The high Ba:Ca ratio in Hobble Creek is likely due to the low ambient Ca concentration, not a high Ba concentration (Table A.3). The Provo River watershed has the largest area, and primarily consists of a combination of sandstone, limestone, alluvium, and volcanic rock types; it eventually flows through Lake Bonneville deposits (clays) as it nears Utah Lake. Similarly, the Spanish Fork River, the second largest of the watersheds, consists of a combination of sedimentary and volcanic rock types along its length, and Lake deposits as it drains into Utah Lake (Figure A.3). The Provo River and Spanish Fork have a relatively higher ambient Ca concentration than Hobble Creek (Table A.3).

The elemental concentrations in river water is determined by a combination of the bedrock and sediment composition, chemical weathering, and groundwater recharge from limestone, sedimentary evaporite, and silicate rock aquifers (Palmer and Edmond 1992). Limestones are primarily composed of calcium carbonate, have relatively high Sr concentration, and are more susceptible to chemical weathering than silicate rock types (Palmer and Edmond 1992). Evaporite deposits are also easily weathered compared to silicate bedrock and have a relatively high Sr content (Palmer and Edmond 1992). Silicate bedrock, in addition to being resistant to weathering, contains relatively low Sr contents compared to limestones and evaporites (Palmer and Edmond 1992). The smaller drainage area of Hobble Creek watershed may have less 
time for groundwater recharge and shorter paths through carbonate bedrock, and weathering processes, which may contribute to its lower Ca concentrations. The Provo River watershed and Spanish Fork watersheds are larger, have more groundwater-rock and weathering interactions, and also consist of bedrock that is relatively higher in $\mathrm{Ca}$ concentration (e.g., limestones) than Hobble Creek.

Despite some remaining uncertainties in the underlying mechanisms driving the water chemistry and elemental uptake from the fish, the models are capable of accurately classifying fish from Utah Lake tributaries and the FES hatchery with relatively low model error (9\%-11\%). This discrimination is important in that it allows me to predict whether a fish is of wild origin, i.e., if the natal signature does not match the FES hatchery signature. Furthermore, the classification models were able to predict which tributary an individual came from based on otolith chemistry, with relatively high accuracy (89\% and 91\%). Identifying where individual fish came from based on otolith chemistry provides a useful tool, potentially increasing the ability to determine if a fish came from a restored stream.

As the June Sucker is endangered and research mortality is discouraged, I was unable to collect naturally spawned fish and thus used hatchery-reared fish as a surrogate. Consequently, I could not identify natal origin directly from the otolith core. However, larval otoliths begin to incorporate elements during egg incubation (Campana and Neilson 1985); therefore, I assumed the core of naturally spawned June Sucker otoliths reflect the elemental signature of the natal tributaries. In addition, the downstream site location of the cages accounts for any lake influence that may be 
observed in the fish otolith from spending time near the mouth of the river in potential rearing habitat. The water chemistry revealed that Utah Lake had significantly higher $\mathrm{Sr}$ :Ca concentrations than the spawning tributaries and the FES hatchery (Table A.2); it is possible this difference may be observed in otolith chemistry taken from a transect across the otolith core to outer edge. In future work or other studies, the trajectory from the core to the outer edge from a wild fish could provide a record of the natal origin, tributary residence time, and possibly spawning events, allowing for a better understanding of life history and habitat use across the fish's life span (e.g., Turner and Limburg 2014).

Future research may benefit from focusing on sampling otoliths from new adult fish of unknown origin, and using the classification models developed to predict if the fish is of wild or hatchery origin. Investigating the use of hard-part chemistry in fin-rays as non-lethal means for determining natal origin in the endangered June sucker may also be a possible avenue that would beneficial for future research (Wells et al. 2003; Wolff et al. 2013). In addition, water samples should continue to be collected to monitor the inter-annual temporal stability of the water chemistry.

The results from this study will allow managers to track progress of June sucker recovery, by providing a tool for managers to determine if a fish is of hatchery or wild origin, and allowing determination of whether or not natural recruitment is occurring into the adult population. In addition, the classification model will aid in evaluating the effectiveness of habitat restoration across different tributaries of varying restoration progress and state of degradation, by predicting which tributaries wild fish were 
spawned in. Similarly these results will help prioritize and direct future restoration plans. Prior to this research, primarily LDA and QDA have been the primary analytical tools used in otolith microchemistry studies; however, my study shows the strength and applicability of classification tree and random forest models for this type of data. In sum we have demonstrated that sufficient differences exist in water chemistry among tributaries, and that June Sucker otoliths reflect the microchemistry of the surrounding ambient water, that knowledge can be used to bridge the gaps remaining in understanding drivers of June sucker recruitment dynamics and prioritizing tributary restoration efforts.

\section{REFERENCES}

Bickford, N., and Hannigan, R. 2005. Stock identification of walleye via otolith chemistry in the Eleven Point River, Arkansas. N. Am. J. Fish. Manag. 25: 1542-1549.

Bond, N.R., and Lake, P.S. 2003. Local habitat restoration in streams: constraints on the effectiveness of restoration for stream biota. Ecol. Manag. Restor. 4(3): 193-198.

Buelow, K.A. 2006. Investigation of movement behaviors of Utah Lake fish: Part I, Utah Lake sucker movement. Crowl Aquatic Ecology Lab. Final Report.

Budy, P., and Schaller, H. 2007. Evaluating tributary restoration potential for Pacific salmon recovery. Ecol. Appl. 17(4): 1068-1086.

Budy, P., Conner, M., Salant, N.L., Macfarlane, W.M. 2015. An occupancy-based quantification of the highly imperiled status of desert fishes of the southwestern United States. Conerv. Biol. DOI: 10.1111/cobi.12513. 
Burkhead, N.M. 2012. Extinction rates in North American freshwater fishes, 1900-2010. Bioscience 62(9): 798-808.

Burr, B.M., and Mayden RL. 1992. Phylogenetics and North American freshwater fishes. In Systematics, Historical Ecology, and North American Freshwater Fishes. Edited by R.L. Mayden. Stanford University Press, Stanford, Calif. pp. 18-75.

Campana, S.E. 1999. Chemistry and composition of fish otoliths: pathways, mechanisms and applications. Mar. Ecol. Prog. Ser. 188: 236-297.

Campana, S.E., and Neilson, J.D. 1985. Microstructure of fish otoliths. Can. J. Fish. Aquat. Sci. 42(5): 1014-1032.

Carlisle, D.M., Falcone, J., and Meador, M.R. 2009. Predicting the biological condition of streams: use of geospatial indicators of natural and anthropogenic characteristics of watersheds. Environ. Monit. Assess. 151(1-4): 143-160.

Cooke, S.J., Bunt, C.M., Hamilton, S.J., Jennings, C.A., Pearson, M.P., Cooperman, M.S., and Markle, D.F. 2005. Threats, conservation strategies, and prognosis for suckers (Catostomidae) in North America: insights from regional case studies of a diverse family of non-game fishes. Biol. Conserv. 121: 317-331.

Cooperman, M., and Markle, D. 2003. Rapid out-migration of Lost River Shortnose sucker larvae from in-river spawning beds to in-lake rearing grounds. Trans. Am. Fish. Soc. 132:1138-1153.

Cutler, D. R., Edwards Jr, T. C., Beard, K. H., Cutler, A., Hess, K. T., Gibson, J., and Lawler, J.J. 2007. Random forests for classification in ecology. Ecology 88(11): 27832792. 
Eldson, T.S., Wells, B.K., Campana, S.E., Gillanders, B.M., Jones, C.M, Limburg, K.E., Secor, D.H., Thorrold, S.R., and Walther, B.D. 2008. Otolith chemistry to describe movements and life-history parameters of fishes: hypotheses, assumptions, limitations and inferences. Oceanogr. Mar. Biol. 46: 297-330.

Gadomski, D.M., Barfoot, C.A., Bayer, J.M., and Poe, T.P. 2001. Early life history of the northern pikeminnow in the lower Columbia River basin. Trans. Am. Fish. Soc. 130(2): 250-262.

Gaston, K. J. 1994. What is Rarity? In Rarity. Edited by M.B. Usher, Chapman \& Hall, London. pp. 11-12.

Gibson-Reinemer, D.K., Johnson, B.M., Martinez, P.J., Winkelman, D.L., Koenig, A.E., and Woodhead, J.D. 2009. Elemental signatures in otoliths of hatchery rainbow trout (Oncorhynchus mykiss): distinctiveness and utility for detecting origins and movement. Can. J. Fish. Aquat. Sci. 66(4): 513-524.

Hand, C.P., Ludsin, S.A., Fryer, B.J., and Marsden, J.E. 2008. Statolith microchemistry as a technique for discriminating among Great Lakes sea lamprey (Petromyzon marinus) spawning tributaries. Can. J. Fish. Aquat. Sci. 65(6): 1153-1164.

Janetski, J.C. 1990. Utah Lake: Its role in the prehistory of Utah Valley. Utah Historical Quarterly 58: 5-31.

Jelks, H.L., Walsh, S.J., Burkhead, N.M., Contreras-Balderas, S., Diaz-Pardo, E., Hendrickson, D.A., and Warren Jr, M.L. 2008. Conservation status of imperiled North American freshwater and diadromous fishes. Fisheries 33(8): 372-407. 
Kauffman, J.B., Beschta, R.L., Otting, N., and Lytjen, D. 1997. An ecological perspective of riparian and stream restoration in the western United States. Fisheries 22(5): $12-24$.

Lee, C-t A. 2006. Laser ablation ICP-MS: data reduction [online]. Available from www.cintylee.org/s/LASERABLATIONICP.pdf

Laub, B., and Budy, P., 2015. Assessing the likely effectiveness of multi-species management for imperiled desert fishes with niche overlap analysis. In Press.

Ludsin, S.A., Fryer, B.J., and Gagnon, J.E. 2006. Comparison of solution-based versus laser ablation inductively coupled plasma mass spectrometry for analysis of larval fish otolith microelemental composition. Trans. Am. Fish. Soc.

135:218:231.

McDonald, J.H. 2014. Handbook of Biological Statistics 3rd ed. In Kruskal-Wallis test. Sparky House Publishing, Baltimore, Md. pp. 157-164.

McKinney, M.L. 1999. High rates of extinction and threat in poorly studied taxa.

Conserv. Biol. 13(6): 1273-1281.

May, R.M., Lawton, J.H., and Stork, N.E. 1995. Assessing extinction rates. In Extinction rates Edited by J.E. Lawton, and R.M. May, Oxford University Press, Oxford. pp 1-

24.

Mayer Jr, F.L., Marking, J.L., Bills, T D., and Howe, G.E. 1994. Bioavailability: Physical, chemical and biological interactions. In Physicochemical factors affecting toxicity in freshwater: Hardness, pH, and temperature. Edited by J.L. Hamelink, P.F. 
Landrum, H.L. Bergman, and W.H. Benson, Lewis Publishers, Boca Raton, FI. pp. $5-22$.

Laub, B.G., Jimenez, J., \& Budy, P. 2015. Application of Science-Based Restoration Planning to a Desert River System. Environmental management, 55(6): 12461261.

Miller, R.R., Williams, J.D., and Williams, J.E. 1989. Extinctions of North American fishes during the past century. Fisheries 14: 22-30, 32-38.

Minckley, W.L., and Douglas, M.E. 1991. Discovery and extinction of western fishes: A blink of eye in geologic time. In Battle against extinction: native fish management in the American West. Edited by W.L. Minckley, and J.E. Deacon, University of Arizona Press, Tuscon, Az. pp. 7-17.

NCR (National Research Council). 1995. Science and the endangered species act. National Academies Press, Washington, D.C.

Olden, J.D., Poff, N.L., and Bestgen, K. R. 2008. Trait synergisms and the rarity, extirpation, and extinction risk of desert fishes. Ecology 89(3): 847-856.

Palmer, M.A., Ambrose, R.F., and Poff, N.L. 1997. Ecological theory and community restoration ecology. Restor. Ecol. 5(4): 291-300.

Palmer, M.R., and Edmond, J.M. 1992. Controls over the strontium isotope composition of river water. Geochim. Cosmochim. Acta 56:2099-2111.

Pangle, K.L., Ludsin, S.A., and Fryer, B.J. 2010. Otolith microchemistry as a stock identification tool for freshwater fishes: testing its limits in Lake Erie. Can. J. Fish. Aquat. Sci. 67:1475-1489. 
Pimm, S.L., Russell, G.J., Gittleman, J.L., and Brooks, T.M. 1995. The future of biodiversity. Science 269: 347-350.

R Core Team. (2012). R: A language and environment for statistical computing. R Foundation for Statistical Computing, Vienna, Austria. ISBN 3-900051-07-0, available from http://www.R-project.org/.

Radant, R.D. 1986. History, biology, and management of the June sucker. Salt Lake City, Utah: Utah Division of Wildlife Resources.

Ricciardi, A., and Rasmussen, J.B. 1999. Extinction rates of North American freshwater fauna. Conserv. Biol. 13(5): 1220-1222.

Roni, P., Beechie, T.J., Bilby, R.E., Leonetti, F.E., Pollock, M. M., and Pess, G.R. 2002. A review of stream restoration techniques and a hierarchical strategy for prioritizing restoration in Pacific Northwest watersheds. N. Am. J. Fish. Manag. 22(1): 1-20.

Santos, J.M., Reino, L., Porto, M., Oliveira, J., Pinheiro, P., Almeida, P.R., Cortes, R., and Ferreira, M.T. 2011. Complex size-dependent habitat associations in potamodromous fish species. Aquat. Sci. 73(2), 233-245.

Scheffer, M. 2001. Ecology of shallow lakes. Kluwer Academic Publishers, Dordrecht. Schiemer, F., Keckeis, H., and Kamler, E. 2002. The early life history stages of riverine fish: ecophysiological and environmental bottlenecks. Comp. Biochem. Physiol. 133(3): 439-449. 
Stromberg, J.C., Bagstad, K.J., Leenhouts, J.M., Lite, S.J., \& Makings, E. 2005. Effects of stream flow intermittency on riparian vegetation of a semiarid region river (San Pedro River, Arizona). River Res. Appl. 21(8): 925-938.

Turner, S.M., and Limburg, K.E. (2014). Determination of river herring natal origin using otolith chemical markers: accuracy as a function of spatial scale and choice of markers. Trans. Am. Fish. Soc. 143(6): 1530-1543.

Veinott, G., and Porter, R. 2004. Using otolith microchemistry to distinguish Atlantic salmon (Salmo salar) parr from different natal streams. Fish. Res. 71:349-355.

Wells, B.K., Rieman, B.E., Clayton, J.L., Horan, D.L., and Jones, C.M. 2003. Relationships between water, otolith, and scale chemistries of westslope cutthroat trout from the Coeur d'Alene River, Idaho: the potential application of hard-part chemistry to describe movements in freshwater. Trans. Am. Fish. Soc. 132(3) 409-424.

Wolff, B.A., Johnson, B.M., and Landress, C.M. 2013. Classification of hatchery and wild fish using natural geochemical signatures in otoliths, fin rays, and scales of an endangered catostomid. Can. J. Fish. Aquat. Sci. 70(12): 1775-1784.

Woodcock, S.H., Munro, A.R., Crook, A.D., and Gillanders, B.M. 2012. Incorporation of magnesium into fish otoliths: determining contribution from water and diet. Geochim. Cosmochim. Acta 94: 12-21.

USDI. 2008. Hobble Creek stream restoration project final environmental assessment. Prepared by Bio-West Inc. for the U.S. Department of the Interior. USFWS. US Fish and Wildlife Service. 1999. June sucker (Chasmistes liorus) recovery plan. US Fish and Wildlife Service, Denver, Co. 
APPENDIX 
Table A.1. Average total length $( \pm S D ; \mathrm{mm}$ ) of June Sucker's at the beginning and end of the cage experiment from the two site locations (upstream and downstream) in the three tributaries (Provo River, Hobble Creek, and Spanish Fork) and the FES hatchery. Included is the nimber of fish from the cages at each site $(\mathrm{N})$, the average temperature $\left({ }^{\circ} \mathrm{C} ; \pm \mathrm{SD}\right)$ and dissolved oxygen (Avg DO; $\pm S D$ ) taken at time of water samples, and the number of fish otoliths from each site that were analysed using LA-ICPMS (otoliths LA).

\begin{tabular}{llllllll}
\hline Stream & Site & $\begin{array}{l}\text { Start } \\
\text { length }\end{array}$ & End length & N & $\begin{array}{l}\text { Average } \\
\text { temp }\end{array}$ & $\begin{array}{l}\text { Average } \\
\text { Do }\end{array}$ & $\begin{array}{l}\text { otoliths } \\
\text { (n) }\end{array}$ \\
\hline Provo River & upstream & $17.7 \pm 1.5$ & $31.2 \pm 6.2$ & 5 & $19.6 \pm 2.4$ & $4.9 \pm 2.7$ & 5 \\
Hobble Creek & upstream & $17.7 \pm 1.5$ & $28.1 \pm 4.6$ & 30 & $18.5 \pm 1.1$ & $3.3 \pm 2.3$ & 18 \\
Spanish Fork & downstream & $17.7 \pm 1.5$ & $17.1 \pm 3.7$ & 10 & $23.92 \pm 3.7$ & $2.6 \pm 2.0$ & 10 \\
FES hatchery & hatchery & $17.7 \pm 1.5$ & $31.6 \pm 4.7$ & 6 & & & 6 \\
Provo River & downstream & $17.7 \pm 1.5$ & $26.4 \pm 3.5$ & 30 & $22.5 \pm 2.2$ & $2.9 \pm 1.8$ & 21 \\
Hobble Creek & downstream & $17.7 \pm 1.5$ & $28.3 \pm 4.9$ & 36 & $20.3 \pm 1.8$ & $3.4 \pm 2.3$ & 20 \\
\hline
\end{tabular}


Table A.2. June Sucker otolith element:Ca concentrations. The values reported are averages of the normalized, background corrected data from the laser ablation transect across the outer perimeter of the otolith.

\begin{tabular}{|c|c|c|c|c|c|}
\hline ID & Stream & Site & LogMg:Ca & LogSr:Ca & LogBa:Ca \\
\hline F3 & FES Hatchery & $F$ & -4.56 & -2.75 & -5.05 \\
\hline F17 & FES Hatchery & $\mathrm{F}$ & -4.36 & -2.75 & -4.99 \\
\hline F20 & FES Hatchery & $\mathrm{F}$ & -4.56 & -2.73 & -4.94 \\
\hline F14 & FES Hatchery & $\mathrm{F}$ & -4.48 & -2.77 & -4.86 \\
\hline F13 & FES Hatchery & $\mathrm{F}$ & -4.82 & -2.72 & -4.97 \\
\hline F12 & FES Hatchery & $\mathrm{F}$ & -4.57 & -2.75 & -5.06 \\
\hline HL1 & Hobble Creek & $\mathrm{HL}$ & -4.45 & -2.75 & -3.47 \\
\hline HL3 & Hobble Creek & $\mathrm{HL}$ & -4.56 & -2.75 & -3.17 \\
\hline HL6 & Hobble Creek & $\mathrm{HL}$ & -4.37 & -2.79 & -3.48 \\
\hline HL9 & Hobble Creek & $\mathrm{HL}$ & -4.63 & -2.73 & -4.02 \\
\hline HL10 & Hobble Creek & $\mathrm{HL}$ & -4.64 & -2.69 & -3.67 \\
\hline HL14 & Hobble Creek & $\mathrm{HL}$ & -4.99 & -2.71 & -3.49 \\
\hline HL20 & Hobble Creek & $\mathrm{HL}$ & -4.43 & -2.70 & -3.45 \\
\hline HL21 & Hobble Creek & $\mathrm{HL}$ & -4.46 & -2.69 & -3.80 \\
\hline HL33 & Hobble Creek & $\mathrm{HL}$ & -4.61 & -2.70 & -3.58 \\
\hline HL36 & Hobble Creek & $\mathrm{HL}$ & -4.32 & -2.72 & -3.63 \\
\hline HL28 & Hobble Creek & $\mathrm{HL}$ & -4.52 & -2.68 & -3.69 \\
\hline HL29 & Hobble Creek & $\mathrm{HL}$ & -4.34 & -2.70 & -3.45 \\
\hline HL39 & Hobble Creek & $\mathrm{HL}$ & -4.55 & -2.71 & -3.68 \\
\hline HL24 & Hobble Creek & $\mathrm{HL}$ & -4.49 & -2.71 & -3.80 \\
\hline HL30 & Hobble Creek & $\mathrm{HL}$ & -4.51 & -2.67 & -3.44 \\
\hline HL11 & Hobble Creek & $\mathrm{HL}$ & -4.71 & -2.72 & -3.82 \\
\hline HL35 & Hobble Creek & $\mathrm{HL}$ & -4.35 & -2.71 & -3.66 \\
\hline HL25 & Hobble Creek & $\mathrm{HL}$ & -4.60 & -2.68 & -4.07 \\
\hline HL17 & Hobble Creek & $\mathrm{HL}$ & -4.50 & -2.71 & -4.03 \\
\hline HL12 & Hobble Creek & $\mathrm{HL}$ & -4.49 & -2.67 & -3.94 \\
\hline HU12 & Hobble Creek & $\mathrm{HU}$ & -4.48 & -2.71 & -3.88 \\
\hline HU9 & Hobble Creek & $\mathrm{HU}$ & -4.38 & -2.68 & -3.48 \\
\hline HU25 & Hobble Creek & $\mathrm{HU}$ & -4.56 & -2.79 & -3.72 \\
\hline HU24 & Hobble Creek & $\mathrm{HU}$ & -4.40 & -2.70 & -3.23 \\
\hline HU22 & Hobble Creek & $\mathrm{HU}$ & -4.44 & -2.70 & -3.61 \\
\hline HU21 & Hobble Creek & $\mathrm{HU}$ & -4.53 & -2.66 & -3.46 \\
\hline HU20 & Hobble Creek & $\mathrm{HU}$ & -4.38 & -2.68 & -3.46 \\
\hline HU19 & Hobble Creek & $\mathrm{HU}$ & -4.46 & -2.69 & -3.28 \\
\hline HU31 & Hobble Creek & $\mathrm{HU}$ & -4.60 & -2.74 & -3.56 \\
\hline HU30 & Hobble Creek & $\mathrm{HU}$ & -4.66 & -2.69 & -3.77 \\
\hline
\end{tabular}


Table A.2. June Sucker otolith element:Ca concentrations (cont.)

\begin{tabular}{|c|c|c|c|c|c|}
\hline ID & Stream & Site & LogMg:Ca & LogSr:Ca & LogBa:Ca \\
\hline HU29 & Hobble Creek & $\mathrm{HU}$ & -4.52 & -2.69 & -3.52 \\
\hline HU28 & Hobble Creek & $\mathrm{HU}$ & -4.48 & -2.65 & -3.50 \\
\hline HU27 & Hobble Creek & $\mathrm{HU}$ & -4.66 & -2.72 & -3.75 \\
\hline HU26 & Hobble Creek & $\mathrm{HU}$ & -4.95 & -2.66 & -3.71 \\
\hline HU7 & Hobble Creek & $\mathrm{HU}$ & -4.48 & -2.70 & -3.70 \\
\hline HU34 & Hobble Creek & $\mathrm{HU}$ & -4.40 & -2.77 & -3.86 \\
\hline HU33 & Hobble Creek & $\mathrm{HU}$ & -4.51 & -2.77 & -3.88 \\
\hline HU32 & Hobble Creek & $\mathrm{HU}$ & -4.24 & -2.74 & -4.03 \\
\hline PL3 & Provo River & $\mathrm{PL}$ & -4.65 & -2.59 & -4.40 \\
\hline PL2 & Provo River & $\mathrm{PL}$ & -4.58 & -2.54 & -4.35 \\
\hline PL1 & Provo River & PL & -5.02 & -2.57 & -4.49 \\
\hline PL14 & Provo River & $\mathrm{PL}$ & -4.88 & -2.59 & -4.56 \\
\hline PL13 & Provo River & PL & -4.90 & -2.61 & -4.61 \\
\hline PL15 & Provo River & $\mathrm{PL}$ & -4.68 & -2.61 & -4.48 \\
\hline PL12 & Provo River & PL & -5.09 & -2.60 & -4.55 \\
\hline PL9 & Provo River & $\mathrm{PL}$ & -4.89 & -2.57 & -4.71 \\
\hline PL8 & Provo River & PL & -4.70 & -2.55 & -4.56 \\
\hline PL7 & Provo River & $\mathrm{PL}$ & -4.53 & -2.61 & -4.27 \\
\hline PL6 & Provo River & PL & -4.76 & -2.56 & -4.35 \\
\hline PL5 & Provo River & $\mathrm{PL}$ & -4.48 & -2.56 & -4.54 \\
\hline PL17 & Provo River & PL & -4.59 & -2.55 & -4.43 \\
\hline PL18 & Provo River & PL & -4.58 & -2.52 & -4.49 \\
\hline PL21 & Provo River & PL & -4.60 & -2.56 & -4.40 \\
\hline PL25 & Provo River & $\mathrm{PL}$ & -4.63 & -2.53 & -4.27 \\
\hline PL26 & Provo River & PL & -5.04 & -2.54 & -4.25 \\
\hline PL27 & Provo River & $\mathrm{PL}$ & -4.63 & -2.57 & -4.56 \\
\hline PL28 & Provo River & PL & -4.65 & -2.59 & -4.69 \\
\hline PL29 & Provo River & $\mathrm{PL}$ & -4.68 & -2.60 & -4.65 \\
\hline PL30 & Provo River & $\mathrm{PL}$ & -4.59 & -2.60 & -4.42 \\
\hline PU2 & Provo River & PU & -4.57 & -2.71 & -4.58 \\
\hline PU1 & Provo River & PU & -4.37 & -2.70 & -4.57 \\
\hline PU5 & Provo River & PU & -4.90 & -2.63 & -4.72 \\
\hline PU4 & Provo River & PU & -4.16 & -2.66 & -4.43 \\
\hline PU3 & Provo River & PU & -4.31 & -2.68 & -4.54 \\
\hline SL10 & Spanish Fork & SL & -4.49 & -2.59 & -4.23 \\
\hline SL9 & Spanish Fork & SL & -4.46 & -2.57 & -4.07 \\
\hline
\end{tabular}


Table A.2. June Sucker otolith element:Ca concentrations (cont.)

\begin{tabular}{llllll}
\hline ID & Stream & Site & LogMg:Ca & LogSr:Ca & LogBa:Ca \\
\hline SL8 & Spanish Fork & SL & -4.40 & -2.54 & -4.29 \\
SL7 & Spanish Fork & SL & -4.45 & -2.52 & -4.27 \\
SL6 & Spanish Fork & SL & -4.58 & -2.59 & -4.24 \\
SL5 & Spanish Fork & SL & -4.98 & -2.49 & -4.19 \\
SL4 & Spanish Fork & SL & -4.44 & -2.48 & -4.25 \\
SL3 & Spanish Fork & SL & -4.60 & -2.53 & -4.31 \\
SL2 & Spanish Fork & SL & -4.48 & -2.51 & -4.10 \\
SL1 & Spanish Fork & SL & -4.48 & -2.54 & -4.22 \\
\hline
\end{tabular}


Table A.3. Water chemistry collected at the three main spawning tributaries of Utah Lake; Provo River, Hobble Creek, and Spanish Fork. Water samples were collected at the upstream site (US) and the downstream site (DS) at each tributary from June thruogh the end of August in 2013. Reported values are the averages of the two $60 \mathrm{~mL}$ replicate samples.

\begin{tabular}{llllllllllll}
\hline Stream & Site & Date & Be & Al & $\mathbf{V}$ & $\mathbf{C r}$ & $\mathbf{M n}$ & $\mathbf{F e}$ & $\mathbf{C o}$ & $\mathbf{N i}$ & $\mathbf{C u}$ \\
\hline Hobble Creek & DS & $6 / 5 / 2013$ & 0.03 & 5.04 & 0.11 & 0.32 & 9.83 & 7.28 & 0.11 & 0.25 & 0.28 \\
Hobble Creek & DS & $7 / 10 / 2013$ & 0.01 & 5.35 & 0.07 & 0.40 & 11.45 & 18.37 & 0.10 & 0.24 & 0.21 \\
Hobble Creek & DS & $7 / 11 / 2013$ & 0.01 & 7.68 & 0.40 & 0.33 & 12.86 & 14.91 & 0.11 & 0.29 & 0.22 \\
Hobble Creek & DS & $8 / 15 / 2013$ & 0.02 & 5.02 & 0.15 & 0.30 & 13.89 & 15.60 & 0.11 & 0.26 & 0.36 \\
Hobble Creek & DS & $8 / 30 / 2013$ & 0.02 & 5.90 & 0.21 & 0.28 & 9.29 & 9.19 & 0.10 & 0.20 & 0.16 \\
Hobble Creek & US & $8 / 15 / 2013$ & 0.01 & 4.47 & 0.02 & 0.27 & 17.16 & 13.92 & 0.11 & 0.23 & 0.17 \\
Hobble Creek & US & $8 / 30 / 2013$ & 0.01 & 6.86 & 0.18 & 0.28 & 11.95 & 8.37 & 0.10 & 0.20 & 0.19 \\
Provo River & DS & $7 / 10 / 2013$ & 0.01 & 2.80 & 0.89 & 0.31 & 22.96 & 19.48 & 0.09 & 0.38 & 0.52 \\
Provo River & DS & $8 / 14 / 2013$ & 0.02 & 4.50 & 1.32 & 0.32 & 23.21 & 25.02 & 0.07 & 0.48 & 0.40 \\
Provo River & DS & $8 / 30 / 2013$ & 0.00 & 1.64 & 1.43 & 0.30 & 28.03 & 25.63 & 0.09 & 0.46 & 0.58 \\
Provo River & US & $6 / 5 / 2013$ & 0.01 & 4.03 & 0.44 & 0.45 & 5.04 & 8.78 & 0.05 & 0.30 & 0.57 \\
Provo River & US & $7 / 10 / 2013$ & 0.01 & 3.12 & 0.47 & 0.38 & 5.88 & 8.69 & 0.06 & 0.31 & 0.80 \\
Provo River & US & $8 / 14 / 2013$ & 0.01 & 2.45 & 1.09 & 0.35 & 4.70 & 17.04 & 0.07 & 0.49 & 0.79 \\
Provo River & US & $8 / 30 / 2013$ & 0.00 & 19.62 & 0.62 & 0.34 & 6.85 & 13.33 & 0.07 & 0.41 & 1.08 \\
Spanish Fork & DS & $7 / 10 / 2013$ & 0.01 & 14.42 & 1.98 & 0.32 & 55.78 & 16.92 & 0.17 & 0.62 & 0.34 \\
Spanish Fork & DS & $8 / 15 / 2013$ & 0.02 & 3.25 & 0.39 & 0.22 & 84.59 & 16.98 & 0.14 & 0.46 & 0.27 \\
Spanish Fork & US & $6 / 5 / 2013$ & 0.01 & 4.84 & 0.57 & 0.34 & 91.73 & 16.21 & 0.17 & 0.50 & 0.39 \\
Spanish Fork & US & $7 / 10 / 2013$ & 0.01 & 4.63 & 1.02 & 0.29 & 72.80 & 10.13 & 0.15 & 0.51 & 0.29 \\
Spanish Fork & US & $8 / 15 / 2013$ & 0.01 & 2.35 & 0.41 & 0.24 & 144.81 & 36.09 & 0.17 & 0.52 & 0.26 \\
FES Hatchery & & $8 / 6 / 2014$ & -0.01 & 16.60 & 0.89 & 0.82 & 0.63 & 8.08 & -0.02 & 0.92 & 7.32 \\
Utah Lake & & $7 / 2 / 2014$ & -0.01 & 4.54 & 5.38 & 0.50 & 0.56 & 3.25 & 0.09 & 1.01 & 0.91 \\
\hline
\end{tabular}


Table A.3. Water chemistry (cont.)

\begin{tabular}{|c|c|c|c|c|c|c|c|c|c|c|c|c|}
\hline Stream & Site & Date & $\mathrm{Zn}$ & As & Se & $\mathrm{Sr}$ & Cd & $\mathrm{Sb}$ & $\mathrm{Ba}$ & TI & $\mathrm{Pb}$ & $\mathbf{U}$ \\
\hline Hobble Creek & DS & $6 / 5 / 2013$ & 22.01 & 0.88 & 0.14 & 210.16 & 2.96 & 0.05 & 60.78 & -0.05 & -0.03 & 0.44 \\
\hline Hobble Creek & DS & $7 / 10 / 2013$ & 80.82 & 0.85 & 0.19 & 223.69 & 2.76 & -0.02 & 108.04 & -0.05 & -0.06 & 0.40 \\
\hline Hobble Creek & DS & $7 / 11 / 2013$ & 139.97 & 0.84 & 0.25 & 220.81 & 2.65 & 0.15 & 190.75 & -0.05 & -0.05 & 0.50 \\
\hline Hobble Creek & DS & $8 / 15 / 2013$ & 23.22 & 0.93 & 0.20 & 216.53 & 2.69 & 0.06 & 82.69 & -0.05 & -0.05 & 0.47 \\
\hline Hobble Creek & DS & $8 / 30 / 2013$ & 69.33 & 1.05 & 0.18 & 227.84 & 2.44 & -0.01 & 101.72 & -0.05 & -0.07 & 0.43 \\
\hline Hobble Creek & US & $8 / 15 / 2013$ & 27.75 & 0.92 & 0.13 & 219.78 & 2.53 & 0.01 & 80.15 & -0.05 & -0.07 & 0.42 \\
\hline Hobble Creek & US & $8 / 30 / 2013$ & 116.43 & 1.03 & 0.17 & 224.89 & 2.59 & 0.03 & 83.86 & -0.05 & -0.08 & 0.45 \\
\hline Provo River & DS & $7 / 10 / 2013$ & 26.04 & 2.98 & 0.58 & 398.31 & 2.46 & 0.16 & 108.77 & -0.05 & -0.03 & 0.88 \\
\hline Provo River & DS & $8 / 14 / 2013$ & 208.33 & 4.06 & 0.80 & 521.37 & 2.66 & 0.22 & 117.65 & -0.05 & -0.05 & 1.28 \\
\hline Provo River & DS & $8 / 30 / 2013$ & 16.25 & 4.35 & 0.75 & 479.14 & 2.54 & 0.27 & 100.86 & -0.05 & -0.05 & 1.20 \\
\hline Provo River & US & $6 / 5 / 2013$ & 23.71 & 1.85 & 0.56 & 375.26 & 3.44 & 0.15 & 75.76 & -0.03 & -0.03 & 0.85 \\
\hline Provo River & US & $7 / 10 / 2013$ & 92.96 & 2.20 & 0.59 & 390.51 & 2.58 & 0.10 & 109.15 & -0.04 & -0.07 & 0.85 \\
\hline Provo River & US & $8 / 14 / 2013$ & 87.16 & 2.04 & 0.71 & 499.78 & 2.89 & 0.16 & 119.70 & -0.03 & -0.06 & 1.55 \\
\hline Provo River & US & $8 / 30 / 2013$ & 62.40 & 2.37 & 0.78 & 468.75 & 2.48 & 0.14 & 106.12 & -0.04 & -0.07 & 1.15 \\
\hline Spanish Fork & DS & $7 / 10 / 2013$ & 62.84 & 3.60 & 0.52 & 652.71 & 2.58 & 0.12 & 118.99 & -0.05 & -0.05 & 1.26 \\
\hline Spanish Fork & DS & $8 / 15 / 2013$ & 20.37 & 1.34 & 0.41 & 488.10 & 2.31 & 0.05 & 100.01 & -0.05 & -0.07 & 0.81 \\
\hline Spanish Fork & US & $6 / 5 / 2013$ & 1.66 & 1.51 & 0.59 & 584.87 & 3.24 & 0.02 & 87.74 & -0.05 & -0.02 & 1.11 \\
\hline Spanish Fork & US & $7 / 10 / 2013$ & 172.69 & 1.76 & 0.42 & 569.78 & 2.69 & 0.11 & 121.05 & -0.05 & -0.05 & 0.92 \\
\hline Spanish Fork & US & $8 / 15 / 2013$ & 17.49 & 1.61 & 0.35 & 621.79 & 2.21 & 0.01 & 110.04 & -0.06 & -0.07 & 0.81 \\
\hline FES Hatchery & & $8 / 6 / 2014$ & 24.67 & 0.93 & 0.07 & 253.67 & 2.59 & -0.31 & 68.81 & -0.02 & 0.23 & \\
\hline Utah Lake & & $7 / 2 / 2014$ & 115.64 & 11.26 & 1.07 & 1314.24 & 3.63 & 0.47 & 125.26 & -0.03 & 0.20 & \\
\hline
\end{tabular}


Table A.3. Water chemistry (cont.)

\begin{tabular}{llllllll}
\hline Stream & Site & Date & Na & Mg & K & Ca & Si \\
Hobble Creek & DS & $6 / 5 / 2013$ & 6834.26 & 11819.07 & 706.2595 & 1231.855 & 41013.4 \\
Hobble Creek & DS & $7 / 10 / 2013$ & 7671.89 & 13902.78 & 1814.799 & 1421.545 & 44400.49 \\
Hobble Creek & DS & $7 / 11 / 2013$ & 7604.46 & 14068.85 & 1785.743 & 1312.949 & 45957.74 \\
Hobble Creek & DS & $8 / 15 / 2013$ & 7424.19 & 13045.51 & 1076.046 & 1349.882 & 44815.64 \\
Hobble Creek & DS & $8 / 30 / 2013$ & 7157.43 & 12403.03 & 1153.974 & 1337.373 & 44346.64 \\
Hobble Creek & US & $8 / 15 / 2013$ & 7283.14 & 12595.79 & 914.9723 & 1367.399 & 43807.42 \\
Hobble Creek & US & $8 / 30 / 2013$ & 7236.79 & 12583 & 1219.58 & 1324.65 & 44898.77 \\
Provo River & DS & $7 / 10 / 2013$ & 16766.83 & 16773.31 & 4076.424 & 3176.804 & 64911.72 \\
Provo River & DS & $8 / 14 / 2013$ & 25119.17 & 23137.72 & 4870.891 & 5018.376 & 77875.59 \\
Provo River & DS & $8 / 30 / 2013$ & 21164.32 & 20362.2 & 5073.436 & 4235.779 & 77221.31 \\
Provo River & US & $6 / 5 / 2013$ & 15477.63 & 15741.45 & 2963.294 & 2584.356 & 63752.89 \\
Provo River & US & $7 / 10 / 2013$ & 16778.96 & 16322.36 & 3314.52 & 2734.44 & 65955.85 \\
Provo River & US & $8 / 14 / 2013$ & 25384.12 & 21895.89 & 4082.205 & 3888.468 & 85215.47 \\
Provo River & US & $8 / 30 / 2013$ & 20631.34 & 19012.82 & 3752.15 & 3194.799 & 79900.36 \\
Spanish Fork & DS & $7 / 10 / 2013$ & 82736.86 & 35720.48 & 6205.046 & 5298.997 & 60605.03 \\
Spanish Fork & DS & $8 / 15 / 2013$ & 45147.65 & 25369.01 & 2333.33 & 3047.856 & 60768.78 \\
Spanish Fork & US & $6 / 5 / 2013$ & 63980.75 & 31476.18 & 3890.23 & 3396.718 & 65067.88 \\
Spanish Fork & US & $7 / 10 / 2013$ & 62547.53 & 30940.84 & 5539.13 & 3595.98 & 65487.5 \\
Spanish Fork & US & $8 / 15 / 2013$ & 81528.55 & 33782.62 & 4318.055 & 3763.058 & 68642.1 \\
FES Hatchery & & $8 / 6 / 2014$ & 2627.38 & 2220.829 & 328.2586 & 5023.625 & \\
Utah Lake & & $7 / 2 / 2014$ & 22466.45 & 6795.053 & 1980.267 & 6608.588 & \\
\hline & & & & & & & \\
\hline
\end{tabular}




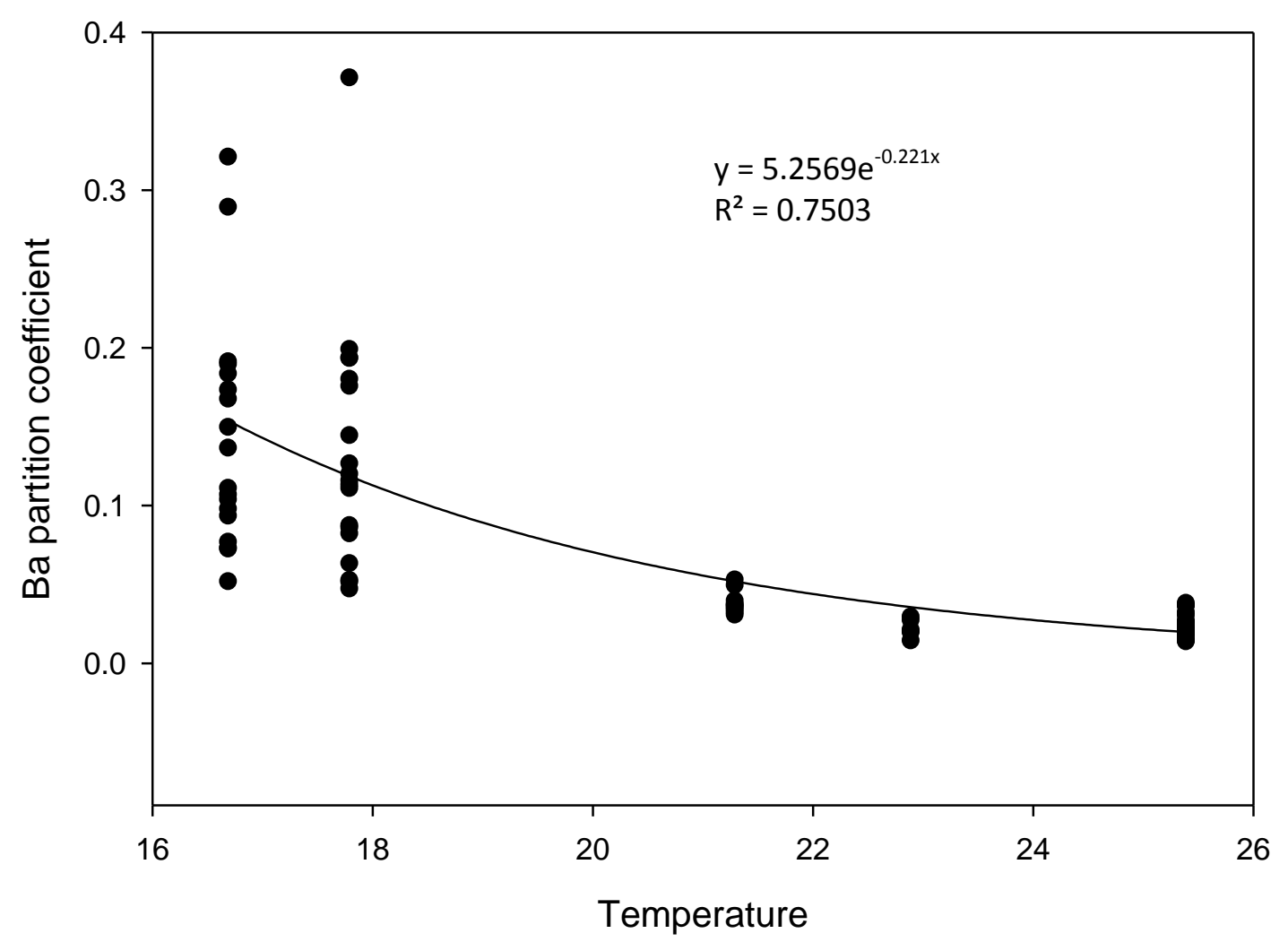

Figure A.1. Exponential model for the June Sucker Ba partition coefficeint as a function of stream temperature $\left({ }^{\circ} \mathrm{C}\right)$. Temperature measurement was taken from each tributary study site location (upstream and downstream) on the August $15^{\text {th }}$ water sampling date. The Ba partition coefficients are calculated as the Ba (ppm) of the water chemistry (from Augusy $15^{\text {th }} 2013$ ) divided by the Ba concentration (ppm) from the June Sucker otolith chemistry. 

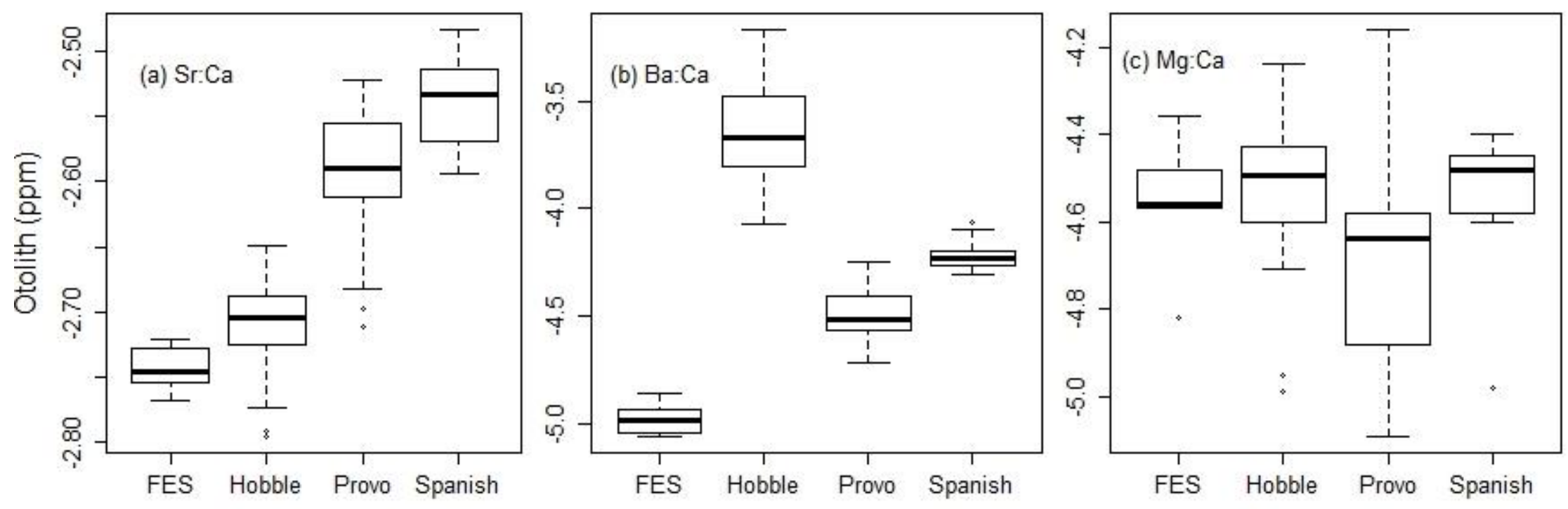

Figure A.2. Box plots of fish otolith elemental concentrations by site, all data were log transformed. Horizontal lines in the boxes represent the median, the top and bottom of the box represent the first and third quintile, the whiskers are the $5^{\text {th }}$ and $95^{\text {th }}$ percentile of the median, and the circles are outliers. The classification models use the combination of elements, there may be overlap in one element but not another. 


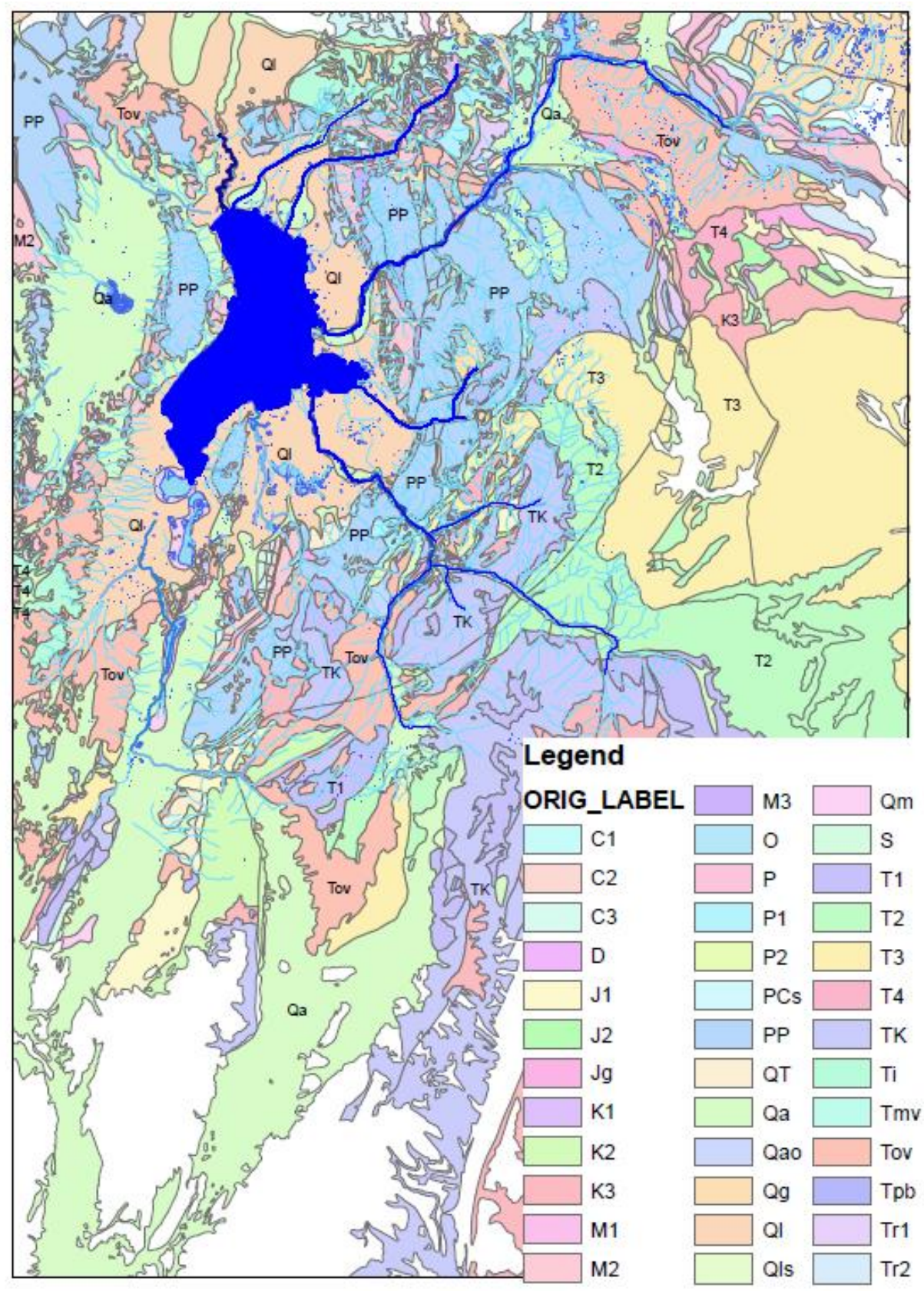

Figure A.3. Geologic map of Utah Lake Utah, and its tributaries. The main-stem of the tributaries are outlined in blue as Spring Creek (top), American Fork Provo River, Hobble Creek, and Spanish Fork (bottom). The river outlined in dark blue, above Spring Creek, is Utah Lake's output the Jordan River, which flows into the Great Salt Lake. The legend on the right represents the different types of geology, and the legend key is continued on the next page. 


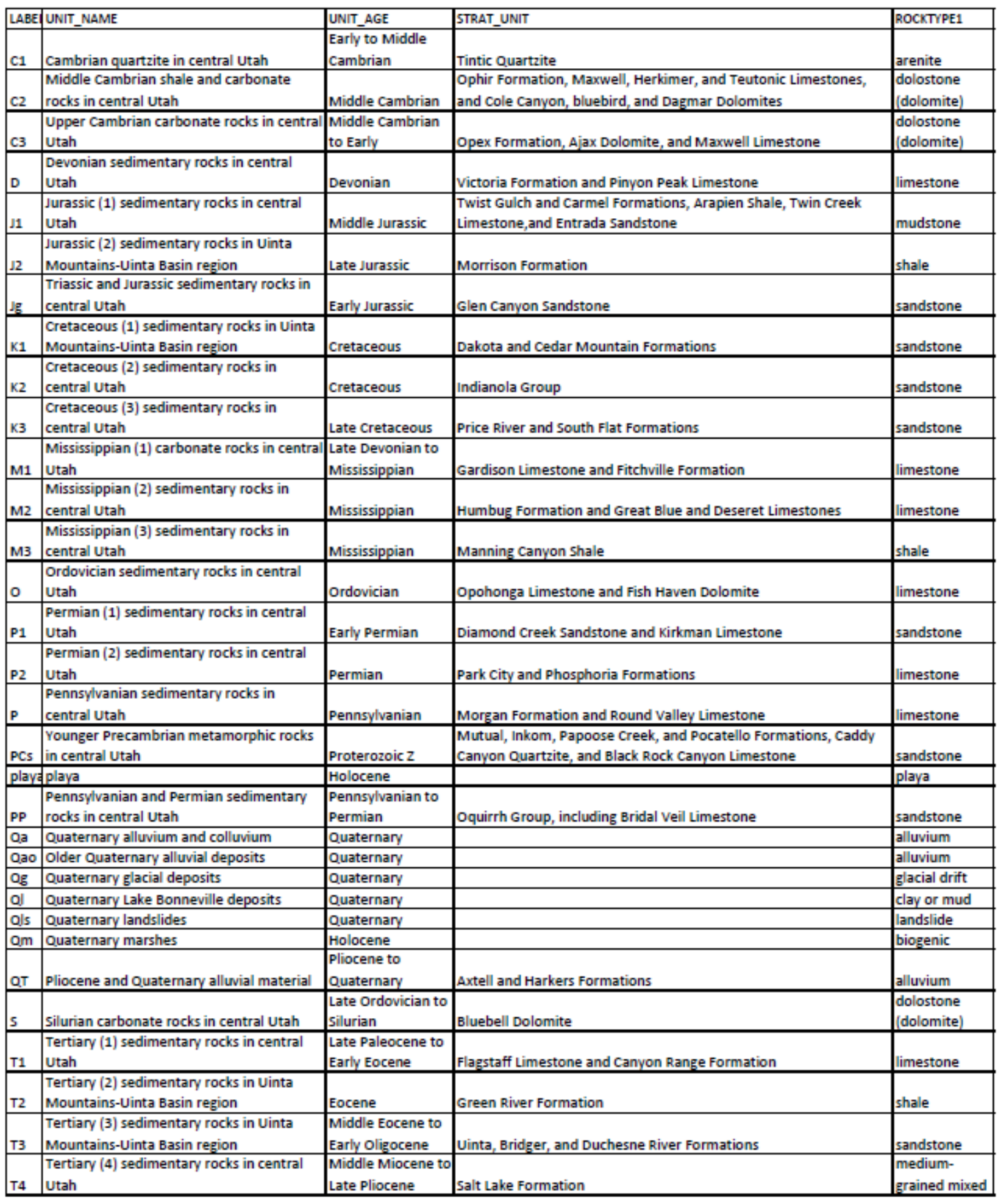

Figure A.3. Legend Key to the geologic map of Utah Lake, Utah, and its tributaries. 